\title{
Accessibility of Women Enterprise Fund among small and Micro Women Enterprise Owners in Tharaka South District, Kenya
}

\author{
Hellen Kawira Machira, Ibuathu Charles Njati, Kubaison S. Thiaine, \\ Guyo Huka, S. \\ Department of Economics School of Business and Economics Meru University of Science and Technology P.O \\ Box 972-60200 Meru \\ Department of Economics School of Business and Economics Meru University of Science and Technology P.O \\ Box 972-60200 Meru \\ Department of Business Management School of Business and Economics Meru University of Science and \\ Technology P.O Box 972-60200 Meru \\ Department of Business Management School of Business and Economics Meru University of Science and \\ Technology P.O Box 972-60200 Meru
}

\begin{abstract}
Since the inception of women enterprise fund in 2009 women entrepreneurs in different parts of the country have accessed the fund; these funds assist women in financing their enterprises and the growth of the enterprises and this contributes towards the overall social and economic development of Kenya as a country. Tharaka south district has made little access into the fund as compared to the neighboring Siakago and Mwingi South Districts that share similar geographical conditions. This study was to examine the factors influencing access to women enterprise fund by women micro and small enterprise owners in Tharaka South District. The study used a descriptive study and was delimited to Tharaka south district only. Stratified random sampling method was be used in selection of the respondents .Questionnaires with structured and unstructured questions were used in collecting primary data. Both qualitative quantitative techniques were used to analyze the data obtained from the field. Statistical package for social sciences (SPSS, for windows version 15.0) was used in data management and analysis. Findings were presented in the form of percentages, frequency tables and graphs.
\end{abstract}

Key words: women groups, financial enterprises, socioeconomic development.

\subsection{BACKGROUND TO THE PROBLEM}

\section{Introduction And Background To The Study}

Although women constitute $52 \%$ of the total Kenyan population, majority of them have been excluded from the formal financial services - for example, few have bank accounts, can access loans and money transfer service. The rural women are more disadvantaged than their urban counterparts as such the fund is designed to address the perennial challenges women face in their desire to venture in income generating activities namely: Cultural factors; high transaction costs and negative myths about banks, (RoK,2008).

Women enterprise fund was established by the government as part of the Kenya government's commitment to one of the millennium development goals on gender equality and women empowerment to provide accessible and affordable credits to support women expand or start new businesses for wealth and employment. The women enterprise fund (WEF) was established in August 2007 and launched in May 2009 as part of the governments' commitment to one of the millennium development goals on gender equality and women empowerment (KIPPRA,2010). It is a flagship project under the social pillar in vision 2030. The fund provides accessible and affordable credits to support women expand or start new businesses for wealth and employment creation. The fund also provides business support services such as capacity building, marketing, promotion of linkages and infrastructure support. Women Enterprise Fund loans reach the target beneficiaries through partner financial intermediaries and directly through Constituency Women Enterprise Scheme (C-WES) (RoK,2008).

According to Ministry of Gender, Children, and Social Services, 92,000 women have benefited from ksh 682 Million disbursed from the fund (RoK, 2005). In Tharaka South, only 44 out 312 registered groups have benefited with a total of ksh 2,200,000 out of an allocation of ksh 5,000,000 in 2012 (http:www.wef.co.ke/component/content/article/36. .About the fund). Women can borrow from as little as ksh 1000 to ksh 500,000 but approvals of the advisory board is necessary for amounts exceeding ksh500,000 (KIPPRA 2010) and; (RoK,2005). The international microfinance consensus is firmly based on a private sector driven development perspective and generally favors a facilitating role of the public sector: putting in place a regulatory framework that allows for unlimited entry of private sector capital and creating a level playing field for all investors and practitioners. This precludes public sector entities to become engaged in retail lending at 
below market rate terms and conditions (KIPPRA, 2010). However, the Indian and Bangladesh governments have established home grown microfinance system that works for poor people majority of whom are women. In Bangladesh, the government created a national apex finance institution that provides low-cost capital to eligible MFIs. Eligibility rules include a good financial track record, a strong focus on reaching the poorer clients and willingness to transfer part of the cost of capital subsidies to the clients (Lois 2004).

According to Stevenson (2005), in Ethiopia, the government introduced microfinance regulation that is quite different from the model introduced elsewhere in Africa. The Ethiopian variety is strongly poverty focused and promotes service delivery to the poorest, especially the rural poor woman. MFIs by law have to be shareholding companies but are also required to retain all earnings as the governments continue providing retail loans. Even if elaborate microfinance policies have been introduced, such as in Nigeria, or have re-introduced targeted lending programs, as in Kenya; perhaps in response to lack of other options to reach the targeted clients.

Kenya's Women Enterprise Fund is a fairly unique program on two accounts. On one hand it goes against mainstream thinking in microfinance that does not endorse public sector involvement in retail credit delivery other than through government banks; on the other is has installed a double implementation strategy as funds are partly placed with reputed financial institutions, (KIPPRA 2010,Abel and Oketch 2009).

Further, Sessional paper No. 2 of 2005 states that promotion of equality of opportunity and elimination of all forms of discrimination based on sex is a functional step that provides necessary conditions for effective development. Empirical studies show that women are more vulnerable to chronic poverty because of gender inequalities such as access to productive inputs such credit, access to and control of property and earned income and inadequate access to education. This is despite increasing women participation in MSEs, as such sessional paper No. 2 of 2005 recommends that the government pursue policies to empower women, increase their access to credit by encouraging them to form SACCOs, promote networking with formal banks and micro-finance institutions.

Women enterprises aid in grass root economic development of a country and women entrepreneurs contribute to the economic development of their families. However women entrepreneurs lack adequate physical capital such as credit which force them into quest for micro-financial assistance (Kuzilwa,2005). Inability to access credit for business is occasioned by factors such as lack of asset as collateral, societal discrimination, poverty and unemployment among others( Ekuman,2001). The objective of this study was therefore to explore factors hindering access of credit specifically from the women enterprise fund by women owners of micro and small medium enterprises in Tharaka South district.

Micro, small and medium enterprises are defined differently in various countries in the world. There is no clear and universally acceptable definition of micro, small and medium enterprises (MSMEs). The number of employees engaged by the enterprises is the more commonly used unit of measurement of the size of a business than the turnover, the degree of formality, or legitimacy of the enterprise; capital investment; and degree of skills per worker (RoK,2005). In the United Kingdom, small enterprises are defined as those enterprises having 1-50 employees, a turnover of not more than $£ 6.5$ million and a balance sheet total of not more than $£ 3.26$ million, while medium sized firm has 51-250 employees, turnover of not more than $£ 25.9$ million and a balance sheet total of not more than $£ 12.9$ million. (Hellen,2002).

In Kenya, Sessional Paper No 2 of 2005 (on development of micro and small enterprises for wealth and employment creation for poverty reduction defines small and medium enterprises (SMEs) as those enterprises employing 10-49 for small enterprises and 50-99 for medium enterprises. Sessional Paper No 2 of 2005) further expanded the definition of MSEs to include all enterprises, both farm and non-farm, employing less than 50 persons. (RoK,2005)

The SME sector in Kenya plays an important role in the socio- economic development of the country. Its significance can be seen in terms of contribution towards economic growth, employment, poverty reduction and development of an industrial (Wanjohi,2007). According to 1999 MSE baseline survey, the number of enterprises has grown to 1.3 Million of which $66 \%$ were located in the rural areas while $48 \%$ were women owned. The SME sector in Kenya contributed $78 \%$ of total employment and $20 \%$ of GDP, according to the Economic survey of 2007. This sector is however faced with constraints which hinder their growth, among them financial access, more so for women entrepreneurs, (RoK 2005).

An enormous body of evidence based on empirical research has grown over the last two decades on success of micro-credit all over the world. Experience and evidences show that micro credit has a positive effect on the socio-economic conditions of the clients, their households and their micro enterprises (Arinaitwe,2006). Access to credit serves dual purpose: capital is invested in micro enterprises and leads to an increase in enterprise and household income as well as increase employment opportunities for the household members and society.

In Kenya, it is recognized that access to credit and financial services is the key to growth and development of any enterprise and more so the MSEs (RoK,2005). Kenya's vision 2030 economic pillar has 
also among other sectors identified financial services as key in driving enhanced growth in the country's GDP (RoK, 2007). Hellen (2002), however, acknowledges that access to credit is one of the main hindrances to enterprise growth in the SMEs sector in the country. Hellen (2002) further avers that relatively few SMEs in the agro-pastoral areas benefit from credit partly because commercial banks and microfinance institutions do not cover these areas. Risks and constraints to credit and commerce in agro-pastoral areas also include insecurity, lack of collateral or land ownership, lack of market information flow and traditional customs (Hellen,2002).In order to address gender related constraints and disparities, the government is pursuing policies to empower women, increase their access to credit by encouraging them to join SACCOs, promote networking with formal banks and MFIs and build institutional capacity of support organizations for gender mainstreaming (RoK,2005).

Sessional Paper No 2 of 2005 recognizes gender equity and productive potential of women who constitute the bulk of the country's labor force and recommends responsive policies that increase equal access to financial services for both men and women. These include establishment of micro-enterprise support programme trust (MESPT) and the women enterprise fund. According to the Baseline survey of 1999, there were 260 organizations (private and public, national and international) with support programs. However, the fact that there are many formal organizations providing credit to Mses while at the same time only $4 \%$ of their credit is accessed from them, implies a gap in their effectiveness (Olawale 2010).

\subsection{Statement of the Problem}

Accessible and affordable credit support gives women entrepreneur's opportunity to expand or start new businesses for wealth and employment. Majority of women though have been excluded from the formal financial services and relatively few MSEs in the agro-pastoral areas benefit from credit. Despite the importance of credit and financial services in business start-up and development, uptake of funds disbursed from the women enterprise fund is currently generally low. In Tharaka South District, only 44 out 312 (14\%) of registered women groups have benefited with a total of ksh 2,200,000 disbursed out of an allocation of ksh 5,000,000 in 2012 (Olawale, 2010).This represents less than a half (44\%) of the total allocation for the constituency. On the other hand, neighboring Siakago and Mwingi South have absorbed $76 \%$ and $68 \%$ respectively of their allocation. Consequently, Tharaka South District being an (Arid and Semi-Arid lands), ASAL area and women enterprise owners having limited sources of funds are not fully accessing the fund that the government is providing under very low interest rate and so the researcher was concerned on what factors hinder these women from accessing the fund yet it may be the only source of capital for their businesses in the area. This situation if not addressed will lead to low capital base which limits enhanced growth and expansion of women owned MSEs and further diminish their ability to contribute to sustainable development and wealth creation. This is supported by various factors such as information sources, social cultural factors and entrepreneurial skills required in accessing the women enterprise fund. This necessitated the need to investigate factors that hindered Tharaka women entrepreneurs from accessing women enterprise fund from the women enterprise fund within Tharaka south District.

\subsection{Objectives of the Study}

\subsubsection{General Objective}

To determine the accessibility of women enterprise fund by women enterprise owners in Tharaka South District.

\subsubsection{Specific Objectives}

1. To determine the effect of information sources on access to women enterprise fund.

2. To find out the influence of socio-cultural factors on access to women enterprise fund

3. To determine the skills relevant for accessing women enterprise fund

\subsection{Research Questions}

1. Which information sources on women enterprise fund affect access to the fund?

2. What socio-cultural factors influence access to the women enterprise fund?

3. In what ways do lack of entrepreneurial culture skills influence access to women enterprise fund?

\subsection{Justification}

The MSE sector in Kenya plays an important role in the socio- economic development of the country. Its significance can be seen in terms of contribution towards economic growth, employment, poverty reduction and development of an industrial base (Woldie 2008). Tharaka South District which is the study area has a population of 310,000 persons of which women constitute slightly more than half of the population (RoK, 2005). Poverty is widespread at $65 \%$ absolute terms with women, children and the weak being the more affected 
as the youth and able bodied men have migrated to towns in search of employment. Female headed households stand at 7,083 out of the total households of 20,239 (RoK, 2005). Income from self employment is low standing at $15 \%$. Poverty and traditional beliefs is a barrier to development in the area which is also food insecure. 69 $\%$ of the population received relief food in 2005 (RoK, 2005).

In view of the economic significance of the MSEs in terms of employment creation and economic development, this research work will be of immense benefit to the Government. The study will also contribute to knowledge in entrepreneurship factors and practices in the agro-pastoral areas for women MSEs in poverty alleviation. In addition, this research will enable both policy makers and stakeholders to identify the strengths and weaknesses of various strategies/incentives; policy areas are required for growth of MSEs through appropriate policies intervention to enable access of credit and affordable financial services.

\subsection{Scope}

The research was based on the study of 172 Saunders (2009) MSEs operated by women in Tharaka South District who operate micro and small women enterprises in Tharaka South District who have or have not accessed women enterprise fund in the recent times.

\subsection{Limitations}

The study did not take into account other women MSEs not registered with the Ministries of Gender. Whereas there are other factors which may affect access to the fund, the study was only delimited to the three variables namely information sources; socio-cultural influence and entrepreneurial skills; Respondents' unwillingness to divulge information and be truthful with information was also a limitation; as such the accuracy and interpretations of the findings may have been negatively affected. Due to the vastness of the area and the area being an ASAL region, there was a limitation of transport hence the researcher had to hire a boda boda so has to move from place to place. The researcher asked for two weeks off from job so as to collect data from the large and sparsely populated area.

\section{Review Of Related Literature}

\subsubsection{Access to Credit}

Various evidence from literature support the fact that women entrepreneurs' lack of business capital and inability to access credit for business are occasioned by factors such as poverty, unemployment, low household and business income, lack of asset collateral and societal discriminations mostly in the developing countries (Peter,2001).

In Kenya among the factors that affect entrepreneurship development in the country is inaccessibility to credit (Hellen, 2002). Women entrepreneurs lack adequate physical capital such as credit and savings for business which force them into quest for financial assistance (Kuzilwa, 2005). Macharia and Wanjiru (1998), in a study of NGOs and Women small scale entrepreneurs in the garment manufacturing sector in Nyeri and Nairobi found that factors that inhibit credit to women include: lack of start-up capital; lack of awareness of existing credit schemes; high interest rates; lengthy and vigorous procedures for loan applications; and lack of collateral security for finance. Sessional paper No. 2 of 2005 also cites lack of access to credit as a major constraint inhibiting growth of SME sector and more so for women entrepreneurs. It further groups problems limiting SME acquisition of financial services as: lack of tangible security coupled with an inappropriate legal and regulatory framework that does not recognize innovative ways for lending to SMEs and the limited access to formal finance due to poor and insufficient capacity to deliver financial services to SMEs. Evidences from literature show that adequate credit aids entrepreneurship performance (Peter, 2001 Kuzilwa, 2005; Cater and Shaw, 2006). The results of such credit assistance to entrepreneurs especially women is often seen in improved income, output, employment and welfare of entrepreneurs (Kuzilwa, 2005). Credit has been found to have positive impact on business performance in Kenya (Peter, 2001, Tanzania Kuzilwa, 2005, Uganda Samiha, 2007). The importance of credit access especially to women in Kenya has led to the establishment of Women Enterprise Fund to address the credit gap and support business development for women (KIPPRA, 2010). The fund is provided by the government at a very low interest rate i.e. $8 \%$ p.a. and the women in Tharaka South District are not adequately accessing it is it that it is not accessible?

\subsubsection{Women enterprise fund}

This is a semi-autonomous Government Agency under the Ministry of Gender, Children and Social development established in August 2007 through a Gazette notice. The objectives of the fund includes: provision of affordable and accessible credit for women enterprise development, capacity building of women beneficiaries and their institutions, promotion of local and international marketing, promotion of linkages of 
micro, small and medium enterprises owned by women, facilitate and support investment in infrastructure that support e.g. markets and incubators for goods produced by women entrepreneurs (KIPPRA 2010).

There are two channels responsible for the provision of women enterprise fund

\section{a).Constituency Women Enterprise Fund (CWES)-(Tuinuke loan- meaning self rising up).}

The funds are given to a Registered Self Help Group of 10 members and above comprising 100\% women or $70 \%$ women and $30 \%$ men. All the leadership positions must be held by women. The group must have a bank account /SACCO FOSA/Post bank and must have been registered for at least 3 months. Loan application forms are provided free of charge from the District Gender and Social Development Offices country wide or Regional Offices based at all provincial headquarters or fund headquarters NSSF building Eastern wing block $\mathrm{D}$ on the $11^{\text {th }}, 12^{\text {th }}$ and $14^{\text {th }}$ floors and can also be down loaded from the website www.wef.co.ke. The loan applications are vetted by the Constituency Women Enterprise Fund Committee (CWETC). The committee is made up of: District Gender and Social Development Officer, The District officer, The local Maendeleo ya Wanawake representative, District youth officer /Youth Enterprise Development Officer, Representative of local financial intermediary partner and women enterprise fund officer (constituency volunteer).

\section{b).Financial Intermediaries Partners (FIS)-(Jimarishe loan-meaning perfecting self).}

The loan is given to individual women, self Help Groups or companies owned by women at $8 \%$ rate of interest per annum on reducing balance. A maximum amount per borrower is ksh.200, 000 and an amount ksh.500, 000 requires W.E.F. board's approval and repayment is to a maximum of 36 months and flexible security differs depending on financial intermediary.

According to KIPPRA (2010) there are some women groups in some counties in Kenya that have successfully benefited from the women enterprise fund: Mutheu Self Help Group in Kitui County are experts in commercialization of indigenous chicken rearing and Marketing at village level with the aim of improved income and food security. The group says that WEF has empowered her members and this is evidenced through improved poultry shelters and construction of a water Kiosk through cost sharing with the Ministry of Water and Irrigation to a tune of Ksh. 15,000/= as profit from improved table banking boosted by WEF loan and the ease of access to loans through table banking. With the Ministry of Water and Irrigation to a tune of Kshs. 15,000/= as profit from improved table banking boosted by WEF loan and the ease of access to loans through table banking and Boarder Labalu is a Women Group in Homabay County. They focus in dairy goat rearing and table banking. WEF loan has enabled them to purchase more goats for all her members who are widows. Currently, they boost of No. 71 goats from the initial of 2 goats. The returns from the milk has enabled them focus on educating orphans, paying dowry for their daughters in law and better still providing better shelter for all the aged members in the group. "None of us has a grass thatched house as we did before," "we are now paying our second loan "said the chairperson

Also KIPPRA (2012) has shown that Nyariginu Project- in Laikipia County specializes in tie and dye, batik, screen printing materials, liquid soap, shampoo, juice and fireless jiko. "Before the WEF loan, they were unable to meet the market demand since the customers ordered more than the resources could support." Chairperson's comment, Members of the group acknowledged that WEF has seen them grow in leaps and bounds. They acknowledged that the returns from the business have assisted them in educating their children and providing for their daily essential household needs. Saadia from Garissa County is in a business of selling miraa and charcoal through the WEF loans. The returns from her businesses have assisted her in educating her children and siblings, taking care of her mother and providing for other daily household needs. She has undertaken training once from KIE offices. The training touched on how to prepare budget, how to save, customer service and record keeping. Kavogoi Women Group-Kakamega County started the project of mushroom planting farming when they got their first loan from WEF. From the proceeds and a little boost from the table banking they invested in a green house where they have planted tomatoes for sale. So far the two projects have given them a good return that has enabled them to comfortably educate their children and meet other financial obligations. Their plan is to expand the green house with the third loan of Ksh. 200,000 to meet the market demand of their products.

\subsubsection{Information sources and Access to Credit}

Sessional paper No. 2 of 2005 on development of micro and small enterprises for wealth and employment creation for poverty reduction states that the major factors facing SMEs in relation to information are its acquisition, capacity to interpret and effectively utilize the acquired information, and dissemination of the same. Without access to timely, simplified, reliable and relevant information on market opportunities, access to credit, production technologies and government regulations and policies, SMEs are unable to survive and grow in the fast- changing, increasingly globalized and highly competitive market environment. Policy on information 
management for SMEs thus seeks to improve the gathering, processing and packing of information in line with the needs of specific SMEs RoK, (2005).

Information with regard to access to credit is a scarce resource to both the rural and urban poor, as well as the deprived SMEs. Evidences from Ekumah and Essel (2001) indicated that SMEs have little access to credit not because of the socio-economic barriers only but also because of inadequacy of information about the services and facilities offered by credit institutions. Ekumah and Essel (2001) concluded that information is a critical variable to empower rural people and MSEs. Without the right information communicated at the right time, accessibility to credit is constrained. More over there's evidence from the study that information flow from the financial institutions to the rural public and vise versa is variedly impeded. The major causes are the imperfect information, lack of transparency form the financial institutions, and asymmetry information in the dealings of the rural financial institutions. The study concluded that any financial institution that does not recognize the relevance of information will continue to impoverish the rural poor as well as MSEs. Kumah and Agbogah (2000) came out with similar findings in their study. Information therefore becomes the power to effectively access credit. Is it that the information on accessibility on Women Enterprise fund is not adequately provided to the woman enterprise owners in Tharaka South district?

\subsubsection{Socio-Cultural Factors and Access to Credit}

Socially accepted norms of behavior and the roles women play in their families can have profound effects on the type of activities in which women can engage, the technologies available to them, the people and agencies with whom they can interact, and the control they can exert over their own capital (Kings and Mucratch, 2002). Legal regulations and customary rules often restrict women's access to and control over assets that can be accepted as collateral such as land or livestock. Hence women are handicapped in accessing financial services as they don't have collateral when required (Agarwal, 2003). Hellen (2002) further avers that relatively few SMEs in the agro-pastoral areas benefit from credit partly because commercial banks and microfinance institutions do not cover these areas. Risks and constraints to credit and commerce in agro-pastoral areas also include insecurity, lack of collateral or land ownership, lack of market information flow and traditional customs. Accessibility to initial capital, even when available, is also a major hurdle for women entrepreneurs. MFIs and commercial banks choose where they locate, thus excluding entrepreneurs in the remote areas (Stevenson and St-Onge,2005, Alila, (2002). RoK (1999) however indicates that the key barrier to accessing credit is lack of innovativeness and responsiveness on the part of capital suppliers that hampers women entrepreneurship.

Njeru and Njoka (1998) pointed out that due to patriarchal social authority structures, women received substantial family support in the start-up stages of their businesses, but later on such support is limited, restricted or withdrawn for fear of husbands losing dominance over their wives. Poor social background has also been cited as barriers to women entrepreneurs (Mutuku, 2006). The situation is worse for disabled women entrepreneurs who have a low self-esteem and view their disability as inability (Hall,1995).

Essel (1996), in a research conducted in Central region of Ghana found that men have more access to rural bank credit than women. The socio-economic barriers were cited as: the fear of women to take risks; lack of awareness leading to reduced access to credit; and the skewed ownership of traditional resources (which can be used as collateral) in favors of men.

Are there unique social cultural factors that bar women from accessing Women Enterprise Fund in Tharaka South District specifically?

\subsubsection{Entrepreneurial Skills}

Business management and entrepreneurial skills are critical in the growth and development of SMEs (RoK, 2005). As such to improve and promote the acquisition of entrepreneurial skills, the government is encouraging universities, polytechnics, technical institutions, and other SMES support organizations to develop demand- driven courses on entrepreneurship and business management, (RoK, 2005). In order to facilitate entry of SME products into the market, Sessional paper no. 2 of 2005 entails that measures be put in place to improve product design and development, commission of market research and support appropriate packaging of goods and services so as to respond to the needs of the international customers.

According to Hill (1987), many MSEs Owners or managers lack managerial training and experience. The typical owner or managers of small businesses develop their own approach to management, through a process of trial and error. As a result, their management style is likely to be more intuitive than analytical, more concerned with day-to-day operations than long-term issues, and more opportunistic than strategic in its concept. Although this attitude is the key strength at the start-up stage of the enterprise because it provides the creativity needed, it may present problems when complex decisions have to be made including acquisition of credit for expansion. A consequence of poor managerial ability is that SME owners are ill prepared to face changes in the business environment. 
Studies on relationship between successful entrepreneurs and less successful ones has also found that SME owner/managers with more managerial, sector experience or prior SME experience as owner/manager tend to correlate with greater growth (Carter \& Shaw,1989). Administrative problems have been cited as a major cause of failure for small businesses. A study by Kazooba (2006) revealed that poor recordkeeping and a lack of basic business management experience and skills were major contributors. Research has also identified inexperience in the field of business, particularly a lack of technical knowledge, plus inadequate managerial skills, lack of planning, and lack of market research (Kuvatko, 1998).These results indicated that lack of financing, lack of management experience, corruption and poor infrastructure are negatively correlated to small business performance.

Olawale and Garwe, (2007) in their study on factors affecting growth of small and medium enterprises found that lack of management experience is also a major cause of small business failure. The study indicates that owners tend to manage businesses themselves as a way of reducing operational costs. According to Gray (1997), MSEs Use the traditional ways of marketing and these no longer give rise to high levels of revenue and product recognition. This factor has also been identified by Burns (1996) in his survey in UK and Nigeria. The survey results showed that $69 \%$ and $70 \%$ of the respondents in the UK and Nigeria respectively agree that poor marketing and sales efforts influence SMEs failure. This implies that the variable is significantly considered as a major factor influencing business failures in the MSEs sector. Gray (1997), further states that economically, it means that if one fails to market or advertise products then turn over and sales volume will be low and that poor marketing and sales efforts are caused by wrong and untimely advertisements or none at all. Lack of information and market detection are other possible causes as well (Burns ,1996) further states that marketing, which is a common source of economies of scale (EOS), spreading cost of advertising over a greater range of output in media markets, is still low and this impact on their growth of SMEs. Cambridge Small business Research Centre (1992), also identified marketing skills among other factors as affecting a firm's growth progression. Furthermore, it appears that when compared to other functions of their business, MSEs owners have a problem with marketing; they appear to give marketing a low priority, often regarding marketing as "something that larger firms do" (Tybee 2003).

\subsection{Theoretical Frame work}

Casson, (2003) is of the view that entrepreneurship theories try to explain characteristics which differentiate successful entrepreneurs from less successful or unsuccessful ones. It is however acknowledged that among the factors that affect entrepreneurship development in the country is inaccessibility to credit (Hellen, 2002). This could be due to various factors. Casson (2003) says that it is the function of entrepreneur to rationally combine forces of production into a new producing organization which include capital for business start off and development.

This study is underpinned on the entrepreneurship theory of (Shane 2003). The theory consists of opportunity discovery, evaluation of the opportunity and the decision to exploit the opportunity. Opportunities are created by the institutional or external environment for those entrepreneurs who could identify them to start or improve their businesses and subsequently their welfare (Shane, 2003). Entrepreneurs' ability to identify and tap such opportunities differs from one entrepreneur to another. It also depends on their ability to access information and willingness to act upon the information in terms of risks; i.e. their attitude (Shane, 2003). Individual attributes affects discovery of entrepreneurial opportunity. It is made of psychological and demographic factors such motives, attitude to risk, education, and training, career experience, age, and social status (Deakins, 1999).

Changes in business environment such as economic, financial, political, legal and socio-cultural factors also affect discovery of opportunities. For example, discovery of business opportunity could be affected by capital availability, income level of the entrepreneur, political stability, laws governing private enterprise and property rights and the desire for enhanced social status by the entrepreneur. Decision to exploit the opportunity depends on the entrepreneurs' level of education, skills, social networks, and credit (Shane, 2003).The decision to exploit opportunity leads to quest for micro- finance which in turn leads to entrepreneurial activity. Kuzilwa (2005) however says that environment plays a greater role in opportunity exploitation than individual attributes.

\subsection{Conceptual Framework}

According to Mugenda (2008), a conceptual framework is a hypothesized model portraying the relationship between variables graphically or diagrammatically. Conceptual framework helps in quickly seeing the proposed relationship and is put to test in order to establish the significance of the proposed relationship. The conceptual framework depicts the relationship of adequacy of information sources, socio-cultural factors and entrepreneurial skills as factors influencing access to credit by micro and small women entrepreneurs. 
Accessibility of women enterprise fund

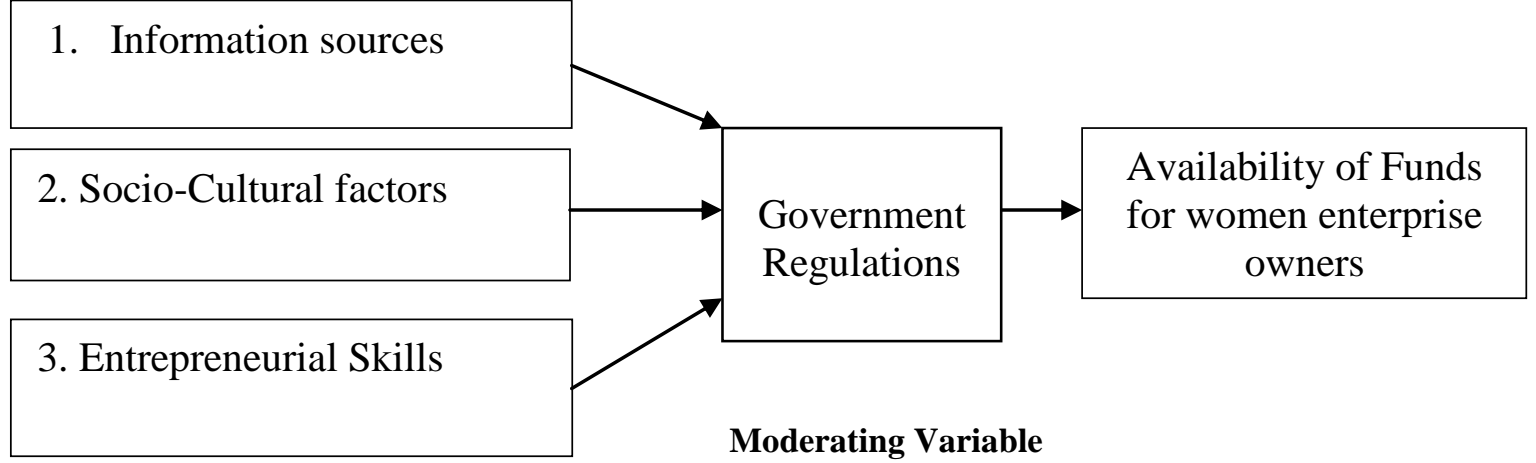

\section{Independent Variables}

\section{Independent variables}

Though women may access the information required on accessibility of the fund, there are no cultural factors hindering them from accessing the fund or they have the required entrepreneurial skills, then the government may give regulations that may hinder these women from accessing the available funds from the women enterprise fund. The small and micro women enterprise owners in Tharaka South are not fully accessing the women enterprise fund and this could be due to the three variables that the researcher looked at. The government may regulate how the women enterprise fund is being availed to the women enterprise owners and may also set the conditions and the requirements to be met before accessing the fund.

\section{Research Methodology}

\subsection{Research Design}

Descriptive research design was adopted in this study. A descriptive research design determines and reports the way things are and uses a pre planned design for analysis (Mugenda and Mugenda, 2003). Cochran (2007) observes that a descriptive research design is used when data is collected to describe persons, organizations, settings, or phenomena. This design was used because the researcher collected the data through interview schedule and questionnaire hence the design was appropriate. The design also had enough provision for protection of bias and maximizes reliability of data (Kothari, 2008).

According to Kumar (2005), descriptive research design studies all the design information to obtain pertinent and precise information concerning the status of the phenomena and draws conclusions from the facts discovered. Using this design the researcher attempts to find answers to questions by analyzing specific variables whereby in this case relates the factors that hinder the women enterprise owners from accessing the women enterprise fund. The design was appropriate since the researcher sought information without manipulating the variables.

\subsection{SAMPLING FRAME}

Table 2

\begin{tabular}{|l|l|l|l|}
\hline Location (Target SMEs) & Total population & Sampling procedure & Sample size \\
\hline Chiakariga & 94 & Purposive & 53 \\
\hline Tunyai & 73 & Purposive & 38 \\
\hline Marimanti & 145 & Purposive & 81 \\
\hline
\end{tabular}

Source: $\operatorname{RoK}(2005)$

A membership register from the District Officer Tharaka South District in the Ministry of Gender, Children and Social Services was used to derive the sample of women owned MSEs.

\subsection{Sample Size and Sampling Technique}

A reasonable sample size is one which ensures that all sources of variations are captured (Cochran, 2007). In this study, the formula below by Kothari (2004) was adopted in calculating the sample size.

$\mathrm{n}=\mathrm{z}^{2} \mathrm{pq} / \mathrm{e}^{2}$

Where:

$\mathrm{n}$ is the desired sample size;

$\mathrm{p}$ is the proportion of the population containing attribute of interest (75\%); q represents (1-p); 
$\mathrm{z}, 1.96$ is the standard variance given at a confidence level (alpha $=0.05)$ e is the acceptable error $(0.05)$

Therefore;

$\mathrm{n}=$ sample size $=(1.96)^{2} 0.75 * 0.25 /(0.05)=172$ respondents

Stratified sampling technique was adopted in obtaining a sample size of 172. Stratified sampling technique ensured that all subsets of the frame were given an equal probability and hence minimizes bias. Each element of the frame therefore had an equal probability of selection. In this study therefore 172 women owners of the MSEs were selected as information respondents.

\subsubsection{Questionnaire for women enterprise owners in Tharaka South Districts.}

Questionnaires were used to get information from the subjects under study. The questionnaire was chosen because of the design and type of study. It is low cost, free from bias of the interviewer and respondents had adequate time to give well thought out answers (Cooper and Schindeur, 2008). The questionnaire had both open and closed ended questions. Closed ended questions were easier to analyze and to administer while open ended ones gave respondents freedom of response.

\subsubsection{Interview schedule for the secretary and the chairlady of the Women groups in Tharaka South District.}

An interview schedule has the advantage of completeness and accuracy. The interview schedule was administered to the Chairlady and the Secretary of the women group because the chair has a link with the national organization dealing with the enterprise fund and the secretary being the custodian of the documents was of great help on the information on the women group.

\subsubsection{Pilot Test}

The objective of conducting a pilot test was to detect weakness in design and instrumentation and to provide alternative data for selection of a probability sample (Kothari, 2008). According to Mugenda and Mugenda (2003), the purpose of pre-testing a tool is to ensure that items in the tool bear the same meaning to all respondents and to assess the average time that is required to administer the instrument .Pilot test was carried out on 20 women enterprise owners and this this comprised of 10 from Marimanti location ,6 from Chiakariga location and 4 from Tunyai division.

\subsubsection{Validity and Reliability}

According to Kumar, (2000) pilot test ensures validity and reliability of the instrument. Reliability is the extent to which any measuring procedure yields the same results on repeated trials (Mugenda,2008). Reliability of the instrument was tested using the Cronbach's alpha(N/(N-1)) i.e. total variance - sum of individual variance/ total variance; and variance is equal to square(score- average). Validity is the accuracy and meaningfulness of inferences, which are based on the research results (Mugenda, 2008). Solution for assuring validity is to use multiple source of information, establish chain of evidence, and have key informants review the report. In this study, the questionnaire was pilot tested on twenty women MSEs owners.

\subsection{Data Collection Procedure}

The researcher got an introduction letter from Meru University and a research permit from the National Council for Research which the researcher presented to the District commissioner of the study area so as to be allowed to carry out the research in the area. The researcher further approached the Division Officers (DO) of the three divisions in the study area so that she could be allowed to collect data. The researcher was introduced to the women group leaders in the study area by the respective division officers.

The researcher booked an appointment with the respective group leaders on the day and venue they would meet to collect the data. To minimize variations in data collection procedures, the questionnaires and schedules were administered personally by the researcher. Structured and unstructured question were used in the questionnaire. Interview schedule was be used on the secretary and the chair of the women group. Structured questions are easier to analyze and to administer while unstructured ones give respondents freedom of response (Kumar, 2000). Public transport was used while collecting data.

\subsection{Data Analysis and Presentation}

Descriptive statistics was used to analyze qualitative and quantitative data. Descriptive statistics provide for meaningful distribution of scores using statistical measures of central tendencies, dispersion and distribution Kothari, (2008). Correlation statistics procedure using statistical package for social science version 
18.0 (SPSS) was used to analyze and generalize the results of analysis to the population. To permit quantitative analysis, data was converted into numeric codes representing attributes or measurements of variables (Mugenda and Mugenda,2003).

Generalizations were then done from the themes about the phenomena in question and interpreted in the light of the available literature (Kumar, 2000). Qualitative analysis is important since it supplements the quantitative analysis to create a better framework to the interpretation and discussion of the findings (Kothari ,2008). Regression analysis will be calculated using the basic regression model: $A W F=\beta_{0}+\beta_{1} \mathrm{II}+\beta_{2} \mathrm{SC}+\beta_{3} \mathrm{ES}$ + e Kumar, (2000)

Where:

AWF is the dependent variable Access to Women Enterprise Fund

II is the Inadequate Information

$\mathrm{SC}$ is the Socio-Cultural factors

ES is Entrepreneurial Skills

$\mathrm{B}_{0}$ is a constant which is the value of dependent variable when all the independent variables are 0 .

$\beta_{1-n}$ is the regression coefficients or change induced by II, SC, and ES on AWF. It determines how much each (i.e. II, SC, and ES) contribute to AWF

$\mathrm{e}$ is the error of prediction.

The results on data were presented in bar graphs, pie charts and tables.

\section{Data Analysis Presentation And Interpretation Of Findings}

\subsection{Demographic Data}

Data was obtained from 149 questionnaires against 172 questionnaires which were administered and returned. This represented $86.7 \%$ response rate, which is considered satisfactory to make conclusions for the study. This high response rate can be attributed to the data collection procedures, where the researcher personally administered the questionnaires and waited for the respondents to fill and pick the filled questionnaires. The researcher had invited the group members for a cup of tea in the area near where the groups met for their meetings. As they took the cup of tea the group leader introduced the researcher to the group members hence creating a good rapport. The researcher distributed the questionnaires to the group members who after filling in the questionnaires gave them back to the researcher. The respondents that could not fill the questionnaires by themselves they were assisted by group leaders and the researcher.

According to Mugenda and Mugenda (2003) a 50\% response rate is adequate, 60\% good and above $70 \%$ rated very good. Based on this assertion, the response rate in this case of $86.7 \%$ falls under the category of 'very good'.

The demographic profile provides information about the population structure and helps in creating a mental picture of the sub-groups that exist in the overall population. Researchers obtain demographic information from the study subjects to understand sample characteristics and to determine if samples are a representative of the population of interest (Kumar,2000). In this study, the researcher investigated the respondent's characteristics by establishing their age, level of education and the legal form of their businesses.

\subsection{Age distribution women entrepreneurs (respondents)}

Table 4.1: Age group of women business entrepreneurs

\begin{tabular}{lll}
\hline Age group & Frequency & Percentage \\
\hline $20-25$ & 36 & 24 \\
$26-31$ & 42 & 28 \\
$32-37$ & 73 & 49 \\
Above 38 & 14 & 9 \\
Total & $\mathbf{1 4 9}$ & $\mathbf{1 0 0}$ \\
\hline
\end{tabular}

The study established age distribution of respondents. Most (54\%) of women business owners Tharaka South District are between the ages of 32 and 37 while $24 \%$ of respondents fall in the age group of 20-25. $28 \%$ women business owners are in the age group 26-31 and 9\% are above the age of 38 .

Table 4.1 above shows that a big percentage of the women entrepreneurs are of middle age $26-37$ with a few above 38 years. This may be due to increased family responsibilities, which have become a woman's concern rather than a male responsibility as society used to assume. Further the findings support the move by the young entrepreneurs to seek self-employment in various sectors of economy. Creativity and innovation 
associated with young people could also be a key factor in starting the business by the young woman in the study area.

\subsection{Reliability of Research Instruments}

The questionnaires used had items that were to be responded to. For reliability analysis Cronbach's alpha was calculated by application of SPSS. The value of the alpha coefficient ranges from 0 to 1 and may be used to describe the reliability of factors extracted from dichotomous (that is, questions with two possible answers) and/or multi-point formatted questionnaires or scales (i.e., rating scale: $1=$ poor, $5=$ excellent) (Patto,2002). A higher value shows a more reliable generated scale. Cooper \&Schindler (2008) has indicated 0.7 to be an acceptable reliability coefficient.

Table 4.2 below illustrates the results of the reliability analysis. It involved questionnaires from ten respondents. As the alpha coefficients were all greater than 0.7, a conclusion was drawn that the instruments had an acceptable reliability coefficient and were appropriate for the study.

Table 4.2 Reliability Analysis

\begin{tabular}{lcc}
\hline Independent Variables & $\begin{array}{c}\text { Cronbach's alpha } \\
\text { Coefficient }\end{array}$ & $\begin{array}{c}\text { No of } \\
\text { Questionnaire }\end{array}$ \\
\hline To determine effect of information sources on access to women enterprise fund & .814 & 8 \\
To find out whether socio cultural factors influences access to women enterprise & .745 & 5 \\
To determine skills relevant for accessing women enterprise fund & .921 & 5 \\
\hline
\end{tabular}

\subsection{Validity Outcome}

Validity is the accuracy or meaningfulness of inferences, which are based on the research results (Kothari ,2008). It is the degree to which a test measures what it's supposed to measure and that the results obtained from the analysis of the data actually represent the phenomenon under study (Mugenda and Mugenda,2003).

The validity of the instrument was established by being given to a lecturer and two experts with experience in SMEs from the Ministry of Labour in the department of SMEs who evaluated the items in relation to the study objectives. They were then rated on a scale of 1(very relevant) to 4(not relevant).The validity was determined through the use of content validity test index obtained by summing items rated 3 or 4 by experts and dividing by the total number of items in the questionnaire. Content validity index of 0.812 was obtained indicating that the validity of the instrument was acceptable as recommended by (Davis,2002). Davis (2002) recommended content validity index of 0.80 for new measures.

\subsection{Level of Education of the Respondents}

As indicated in Table 4.3, the study found that majority (61\%) of the entrepreneurs had primary level as their highest level of education. They are followed by $21 \%$ of respondents had secondary education A- Level graduates were represented by $13 \%$ while only $5 \%$ had acquired college or university education. This implies that the women entrepreneurs in the small and micro enterprises in the study area were of mixed academic qualifications. However, it should be noted that majority had at least primary level qualification which is considered a level that will accord the students the basic foundation for mastery of a given skill. In line with Deakins (1999), observation that individual attributes affects discovery of entrepreneurial opportunity and such attributes are made of psychological and demographic factors which include education and training and individual has received.

Table 4.3: Level of education of the respondents

\begin{tabular}{llc}
\hline Education level & Frequency & Percent \\
\hline & 91 & $61 \%$ \\
Primary level & 31 & $21 \%$ \\
Secondary level & 19 & $13 \%$ \\
A - level & 8 & $5 \%$ \\
University/ college & $\mathbf{1 4 9}$ & $\mathbf{1 0 0 \%}$ \\
Total &
\end{tabular}




\subsection{Legal form of Business}

The study sought to investigate the legal form of business as sole proprietorship, partnership or company. Table 4.2 indicates that (44\%) of the respondents had registered their business as sole proprietorship while $(43 \%)$ were in partnership, while the rest $(13 \%)$ were in a company form of business.

Table 4.4 Legal form of business

\begin{tabular}{lll}
\hline Legal form of business & Frequency & Percent \\
\hline Sole proprietor & 42 & $44 \%$ \\
Partnership & 41 & $43 \%$ \\
Company & 12 & $13 \%$ \\
Total & $\mathbf{9 5}$ & $\mathbf{1 0 0 \%}$ \\
\hline
\end{tabular}

Reddy and Zhao (2000) noted that forming a joint partnership with foreign firms is clearly a favorable strategy for any SME wishing to exploit firm specific assets owned by foreign partners and hence increase competitiveness of the SMEs in the local and global markets due to technology transfers.

Majority of the managers prefer sole proprietorship because of its advantages for small firms compared to other forms of businesses. This includes remittance of individual tax returns, the amount of which is less compared to company tax. Inability to raise required capital could also is a reason for partnership.

\subsection{Information source on women enterprise fund}

This is based on the first objective of the study which is to determine the effect of information sources on access to women enterprise fund. Policy on information management for SMEs seeks to improve the gathering, processing and packing of information in line with the needs of specific SMEs (RoK,2005). Without access to timely, simplified, reliable and relevant information on market opportunities, access to credit is highly affected and SMEs are unable to survive and grow in the fast-changing, increasingly globalized and highly competitive market environment. It is on this basis that the researcher sought data that could analyze how the source of information interacted with women enterprise fund accessibility.

\subsubsection{Awareness level of women enterprise funds}

The study sought information regarding the awareness level of women enterprise funds in Tharaka South District. Data was analyzed and presented in table 4.5.

Table 4.5: Awareness level of women enterprise funds

\begin{tabular}{cll}
\hline Responses & Frequency & Percent \\
\hline Yes & 36 & 24 \\
No & 113 & 76 \\
Total & $\mathbf{1 4 9}$ & $\mathbf{1 0 0 . 0}$ \\
\hline
\end{tabular}

Table 4.5 indicates that, $76 \%$ of respondents were not aware that women enterprise fund was available for them to acquire loans while $24 \%$ of respondents had the knowledge of such services in the district. This large number of women entrepreneurs not being aware of women enterprise funds was attributed to unavailability of effective programs to disseminate information to entrepreneurs in the district. Many women in the district do not own a radio or television or do they even access the newspapers which are mainly used by enterprise fund to deliver information. The finding agrees with Macharia \& Wanjiru (1998) study of NGOs and Women small scale entrepreneurs in the garment manufacturing sector in Nyeri and Nairobi that found out that one of the factors that inhibit credit to women included lack of awareness of existing credit schemes for entrepreneurs in the study area.

\subsubsection{Source of information on women enterprise fund}

The research sought information on how the women entrepreneurs were informed about the women enterprise fund. From the findings as shown in figure 4.1, it appeared that majority (47\%) of entrepreneurs obtained the information from women groups, $26 \%$ of respondents acknowledged media as their source while banking institutions were identified by $9.4 \%$. It is worth noting that Churches and barazas provided information to $11 \%$ and $9 \%$ of respondents respectively. This was attributed by the fact that more women groups in the region were engaged in supporting women to come up with viable business ideas for financial support. Ekumah and Essel (2001) concluded that information is a critical variable to empower rural people and SMEs. Without the right information communicated at the right time, accessibility to credit is constrained. More over there's evidence from the study that information flow from the financial institutions to the rural public and vise versa is 
variedly impeded because they rely mostly on informal channels of communication such as social group meetings.

\section{Figure 4.1: Source of information on women enterprise fund}

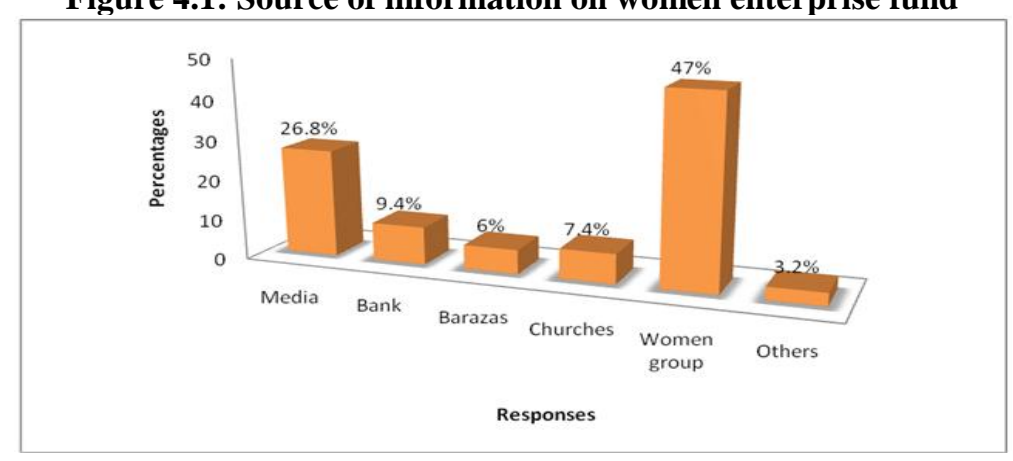

\subsubsection{Effort to access funds from women enterprise fund}

The women enterprise fund was conceptualized to help women entrepreneurs access the business funds in all regions of Kenya. In Tharaka South district, only 44 out 312 registered groups have benefited with a total of ksh 2,200,000 out of an allocation of ksh 5,000,000 in 2012 (http:www.wef.co.ke/component/content/article/36 .About the fund). This observation led the researcher to seek information on whether the women entrepreneurs had attempted to access the funds. The results were analyzed and presented in figure 4.3 below. The item was analyzed in line with Shane's theory which advocates for deliberate effort of searching for opportunities created by the institutions or external environment. Entrepreneurs' ability to identify and tap such opportunities differs from one entrepreneur to another. It also depends on their ability to access information and willingness to act upon the information in terms of risks; i.e. their attitude (Shane, 2003).

Figure 4.2: Distribution of responses on whether effort was made to access the funds

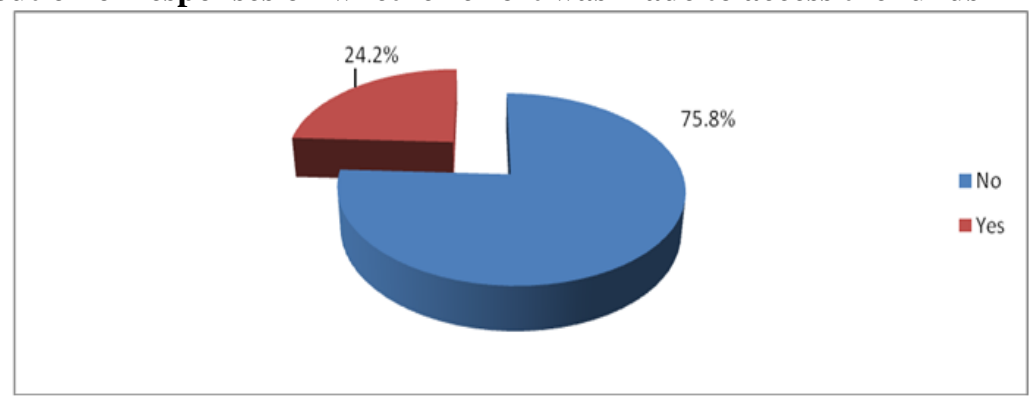

Figure 4.2 indicates that majority (75.8\%) of respondents had not made efforts to access the fund while only $24.2 \%$ of respondents had attempted to access the fund. This implied that though the entrepreneurs had information about the fund they were still reluctant to seek the loan from the fund.

\subsubsection{Institutions offering services of women enterprise fund}

The researcher sought to establish the approaches institution for women fund used; data was collected analyzed and presented in figure 4.3 below. It was found out that majority (37\%) of respondents approached women groups an indication that they were relied on for information dissemination in rural Kenya. The study also revealed that $34 \%$ approached microfinance institution for women enterprise funds as $19 \%$ went to mainstream banks for similar assistance. It was further noted that other $10 \%$ approached other institutions such as churches and investment groups in the district.

Figure 4.3: Distribution of responses on approached institutions by women enterprise owners. 


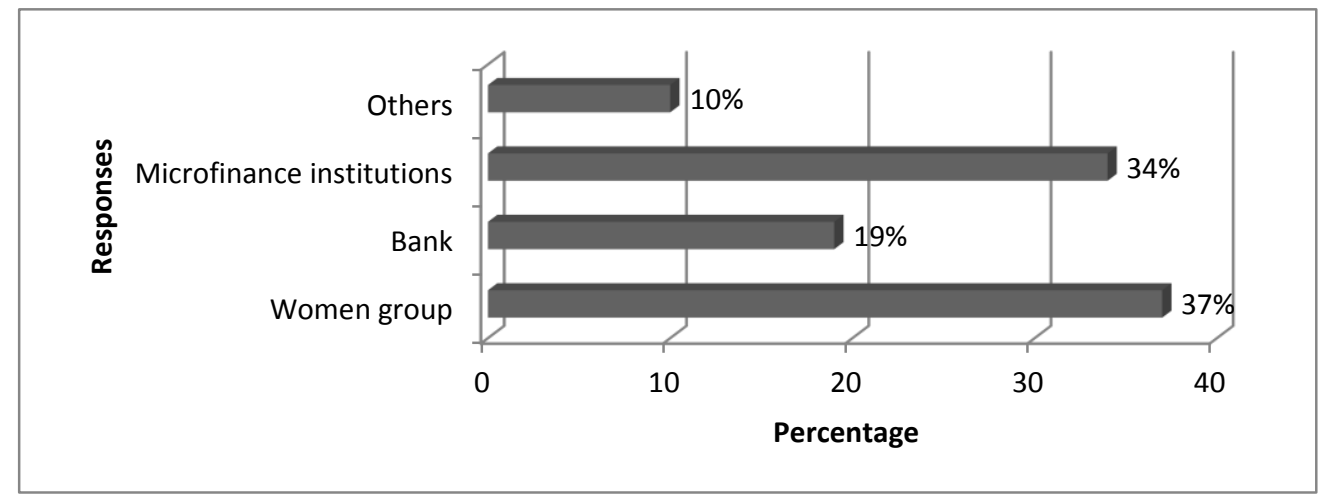

\subsubsection{Loan eligibility from micro finance institutions}

The study investigated loan legibility and found out that $69 \%$ of respondents were not legible for the loan while only $24 \%$ were legible. The reasons for non eligibility were also sought and responses to open ended questions were provided in figure 4.4 below. The findings were in contrast with the international microfinance consensus that asserts that putting in place a regulatory framework that allows for unlimited entry of private sector capital and creating a level playing field for all investors and practitioners will allow all firms to grow and acquire capital for expansion.

Figure 4.4: Distribution of responses on whether women entrepreneurs were eligible for the loan

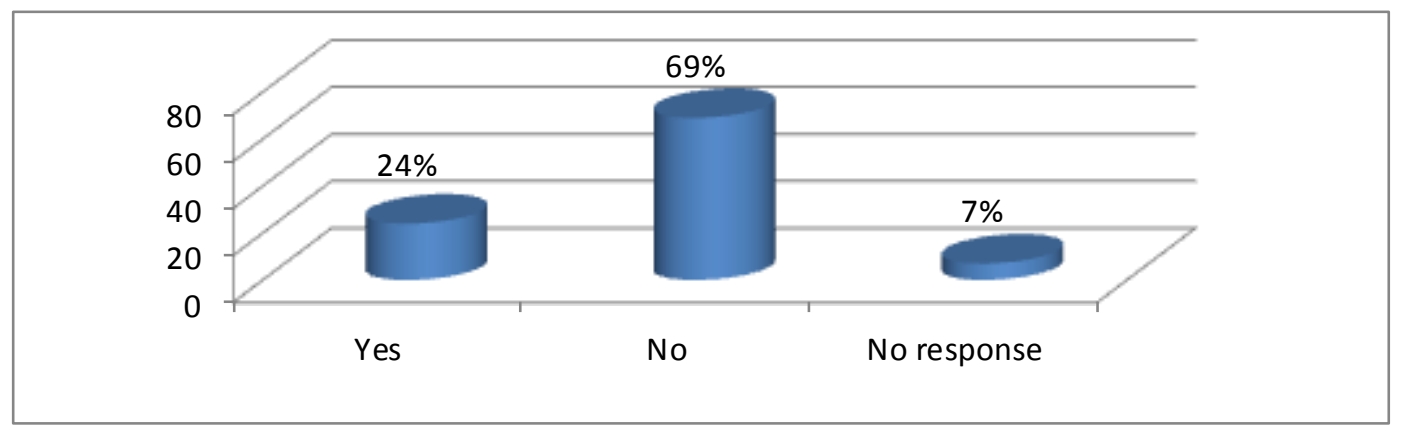

The results on why some women entrepreneurs were not eligible for the women loan ranged from lack of up to date business records at $33 \%$, non viability of business at $24 \%$, poor credit history (18\%), and some business being considered risky. It was revealed that majority (59\%) of respondents considered lack of guarantor or collateral as their main impediment to loan acquisition from women enterprise fund. This is supported by Kenya Vision 2030 which noted that rural women are more disadvantaged than their urban counterparts as such the fund is designed to address the perennial challenges women face in their desire to venture in income generating activities (enterprise development), namely: Cultural factors; high transaction costs and negative myths about banks. This was noted to affect the loan uptake by rural woman ( RoK, 2008).

Table 4.6: Distribution of responses on why women enterprise owners were not eligible for the loan

\begin{tabular}{lll}
\hline Reasons & Frequency & Percentage \\
\hline Lacked up to date business records & 49 & 33 \\
Business considered not viable & 35 & 24 \\
Lacked collateral/guarantors & 88 & 59 \\
Poor credit history & 27 & 18 \\
Business considered risky & 21 & 14 \\
\hline
\end{tabular}

$\mathrm{N}=\mathbf{1 4 9}$

\subsubsection{Loan application from women enterprise fund}

Data on loan application was collected, analyzed and presented as shown in table 4.6. Ekumah and Essel (2001) observed that information is a critical variable to empower rural women and SMEs. Without the 
right information at the right time, accessibility to credit is constrained. This can be explained by $84 \%$ of respondents who did not apply for the loans from women enterprise funds.

Figure 4.5: Distribution of responses on whether the women respondents applied for the loan

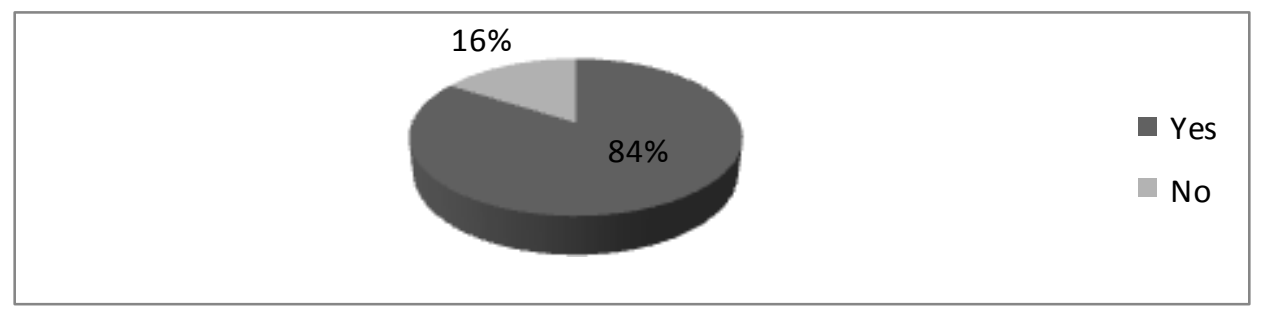

\subsubsection{Successful loan applications on women enterprise fund}

The study analyzed the rate of successful loan applicants and identified that majority (87\%) of respondents were successful on loan application. The remaining participants (13\%) were not successful. This indicates that once a woman entrepreneur was eligible for the loan then there were high chances of her business being successful on loan application. The findings concur with Ekumah and Essel (2001) research which found out that SMEs have little access to credit not because of the socio-economic barriers only but also because of inadequacy of information about the services and facilities offered by credit institutions. Figure 4.6 illustrates the findings of this research.

Figure 4.6: Distribution of responses on whether women the applicants were successful

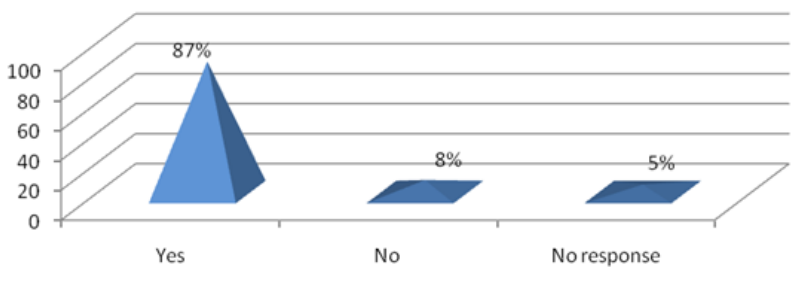

\subsubsection{Uses of women enterprise loan among women groups}

The SME sector in Kenya plays an important role in the socio- economic development of the country. Its significance can be seen in terms of contribution towards economic growth, employment, poverty reduction and development of an industrial base Wanjohi, (2007). It was based on this premise that the researcher sought information on the uses of acquired loan from Women enterprise fund. Table 4.7 summarized the research findings regarding the uses of acquired loan.

Table 4.7: Distribution of responses on uses of the loan by women group members

\begin{tabular}{lll}
\hline Uses of the loan & Frequency & Percent \\
\hline Start business & 25 & 17 \\
Expand business & 64 & 43 \\
Buy land & 24 & 16 \\
Recreational & 27 & 18 \\
Any other & 9 & 6 \\
Total & $\mathbf{1 4 9}$ & $\mathbf{1 0 0}$ \\
\hline
\end{tabular}

Table 4.7 indicates that business expansion is the major role of women finance fund as majority (43\%) of respondents in the study area had used the funds to expand the business. Other uses of the fund were shown to facilitate the start of business at $17 \%$, buying land at $16 \%$ and recreational expenses at $18 \%$. It was also discovered that about $6 \%$ had used the money for other activities such as buying of clothes, education and medical care amongst others. The results concured with (Arinaitwe,2006) observations that experience and evidences show that micro credit has a positive effect on the socio-economic conditions of the clients, their households and their micro enterprises. Access to credit serves dual purpose: capital is invested in micro enterprises and leads to an increase in enterprise and household income as well as increase employment opportunities for the household members and society (KIPPRA,2010).

\subsection{Social cultural factors facing women enterprise owners in Tharaka South District}

According to Kings and McGrath (2002) socially accepted norms of behavior and the roles women play in their families can have profound effects on the type of activities in which women can engage, the 
technologies available to them, the people and agencies with whom they can interact, and the control they can exert over their own capital. Based on this assertion the researcher sought to analyze socio-cultural activities likely to influence the women entrepreneurs access the women fund. The data were collected, analyzed and presented as shown below. Figure 4.7 illustrated the response on whether socio-cultural factors affected the access of women enterprise fund.

Figure 4.7: Distribution of responses on whether socio-cultural factors affect the accessing of women enterprise loans Tharaka South District

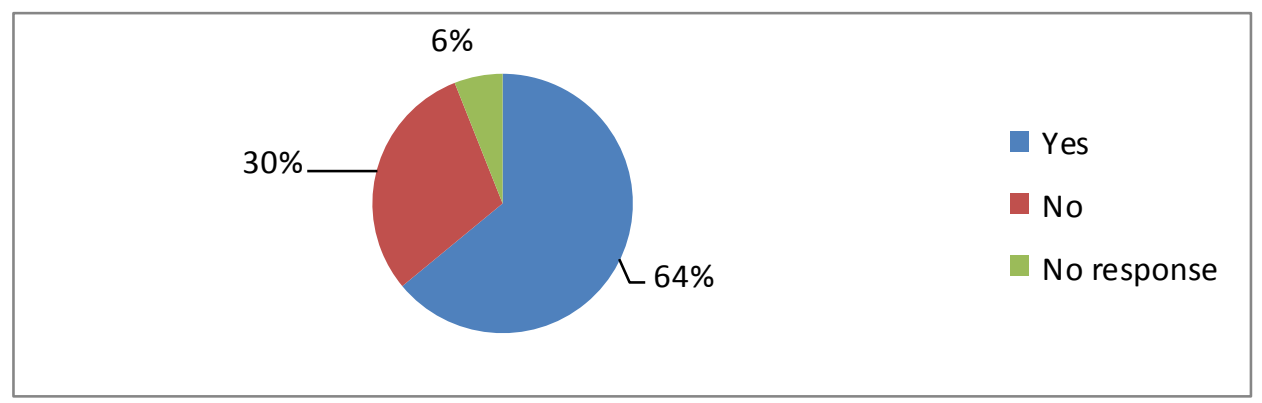

The figure indicated that $64 \%$ of respondents agreed that socio-cultural factors affected the access of women enterprise fund. Those who did not agree were represented by $30 \%$ of respondents. However, a marginal $6 \%$ did not answer this item. This agrees with Kings and McGrath (2002) who argued that socially accepted norms of behavior and the roles women play in their families can have profound effects on the type of activities in which women can engage, the technologies available to them, the people and agencies with whom they can interact. It was also noted by (Agarwal 2003) that legal regulations and customary rules often restrict women's access to and control over assets that can be accepted as collateral such as land or livestock. Hence women are handicapped in accessing financial services as they don't have collateral when required.

Table 4.8: Rating of participants' opinion on various socio-cultural statements on access to finance

\begin{tabular}{|c|c|c|c|c|c|c|}
\hline \multirow[b]{2}{*}{ Statement } & \multicolumn{4}{|c|}{ Response \% } & \multirow[b]{2}{*}{ SD } & \\
\hline & SA & A & $\mathrm{U}$ & D & & $\begin{array}{l}\text { Mean } \\
\text { Score }\end{array}$ \\
\hline $\begin{array}{l}\text { Poor education is a hindrance for women to access } \\
\text { finance }\end{array}$ & $35.6 \%$ & $36.8 \%$ & $16.1 \%$ & $6.9 \%$ & $4.6 \%$ & 3.92 \\
\hline $\begin{array}{l}\text { Religious affiliation affects borrowing of loans for } \\
\text { business }\end{array}$ & $34.8 \%$ & $35.6 \%$ & $6.9 \%$ & $17.6 \%$ & $4.1 \%$ & 3.68 \\
\hline $\begin{array}{l}\text { Gender discrimination against women is a barrier to } \\
\text { entrepreneurial activity }\end{array}$ & $44.8 \%$ & $35.6 \%$ & $6.9 \%$ & $8.6 \%$ & $4.1 \%$ & 4.08 \\
\hline $\begin{array}{l}\text { It is risky to apply for business loans from financial } \\
\text { institutions }\end{array}$ & $42.5 \%$ & $28.7 \%$ & $6.9 \%$ & $14.9 \%$ & $7 \%$ & 3.85 \\
\hline
\end{tabular}

The respondents were requested to rate their level of satisfaction with socio-cultural factors on given statements on a five-point likert scale ranging from 1 to 5 (where $\mathrm{I}=$ strong disagree, while $5=$ strongly agree). The higher the score, the higher was the level of satisfaction with the effect of the statement on access of women enterprise fund, and vice versa. Note that for each statement/socio cultural factor a mean score was calculated. The mean score ranges from 1 to 5, and was used as a guide in ranking the statements so as to understand how the respondents generally varied in their responses on the various socio-cultural factors in the study area. This helped to distinguish the importance of each factor and aspect to the respondents. Table 8 shows the distribution of their responses on socio-cultural factors with gender discrimination being the most predominant factor followed by poor education and risks involved in loan application and religious affiliation in that order. In order to address gender related constraints and disparities, the government is pursuing policies to empower women, increase their access to credit by encouraging them to join SACCOs, promote networking with formal banks and MFIs and build institutional capacity of support organizations for gender mainstreaming (RoK,2005).

Table 4.9: Distribution of responses on other socio-cultural factors influencing access of women enterprise fund

\begin{tabular}{lll}
\hline Response & Frequency & Percent \\
\hline Negative experiences with loan institutions & 49 & 33 \\
Fear of unknown & 35 & 24
\end{tabular}




$\mathbf{n = 1 4 9}$\begin{tabular}{lll} 
Cultural roles & 88 & 59 \\
No response & 11 & 7 \\
\cline { 2 - 3 }
\end{tabular}

Other factors likely to affect the acquisition of women enterprise fund were exhaustively sought from the respondents and the outcome was presented in table 4.9 as shown above. It was established that cultural roles affected the access of women enterprise fund more that negative experience with loan institutions. This study also revealed that fear of unknown was a socio-cultural hindrance to loan access

\subsection{Entrepreneurial skills among micro enterprise owners}

The entrepreneurial skills were established in order to answer research question that sought to investigate the effect of entrepreneurial skills on access of women enterprise fund. Studies have found out that SME owner/managers with less managerial, sector experience or prior SME experience tend to correlate with lesser growth Carter \& Shaw (1989). As a result, their management style is likely to be more intuitive than analytical, more concerned with day-to-day operations than long-term issues, and more opportunistic than strategic in its concept. Although this attitude is the key strength at the start-up stage of the enterprise because it provides the creativity needed, it may present problems when complex decisions have to be made including acquisition of credit for expansion

\subsubsection{Technical training received by micro and small enterprises}

This research also analyzed technical training attended by the women entrepreneurs of the selected businesses in Tharaka south district. The results were presented in figure 4.10; majority (64\%) of participants had not attended technical training related to their businesses while $30 \%$ indicated that they have attended a technical training in line with their business operations. This implied that most businesses owned by women in Tharaka south district were being operated by owners who had no technical knowledge acquired from institution. However, administrative problems have been cited as a major cause of failure for small businesses. A study by Kazooba (2006) revealed that poor record keeping and a lack of basic business management experience and skills were major contributors of business disintegration. The result of this research was in line with (Kuratko,1988) argument that identified inexperience in the field of business, particularly a lack of technical knowledge, plus inadequate managerial skills, lack of planning, and lack of market research for women SMEs.

Figure 4.8: Response on whether entrepreneurs have attended technical training related to enterprise operations

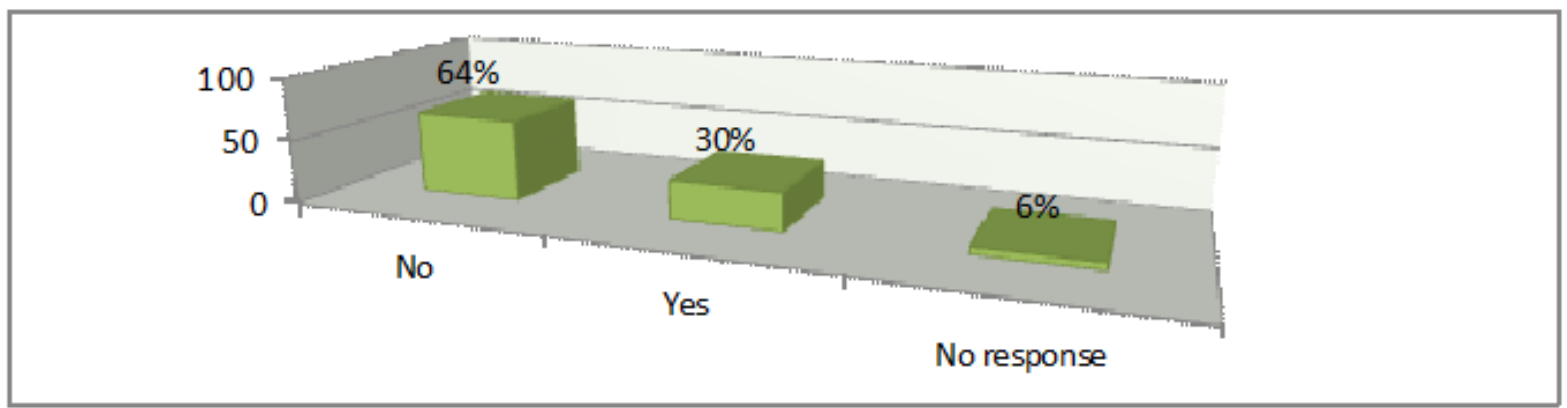

The research also sought to establish why some women entrepreneurs had not attended the technical training related to their business operations. The data was collected in this regard, analysed and presented as shown in table 4.11. The findings were similar to a study carried out by Woldie (2008), on perceptions of business challenges facing Malaysian SMEs, which indicated that factors related to human capital were observed to be the greatest challenge facing the businesses.

The factors were indicated by dominance of unskilled workforce in the industry and lack of motivation among the workforce, there was also lack of managerial and marketing skills as well as low labour productivity. In a study carried out by Woldie (2008) on perceptions of business challenges facing Malaysian SMEs, findings indicated that factors related to human capital were observed to be the greatest challenge facing the businesses. The factors were indicated by dominance of unskilled workforce in the industry and lack of motivation among the workforce, there was also lack of managerial and marketing skills as well as labour productivity.

Table 4.10: Distribution of responses on reasons why Tharaka South District entrepreneurs had not attended any training programs 


\begin{tabular}{lll}
\hline Reasons & Frequency & Percent \\
\hline There was no training opportunities & 51 & 34 \\
Trained only women group leader & 33 & 22 \\
Lacked finance to meet cost & 63 & 42 \\
Time constrain & 29 & 20 \\
Education level & 21 & 14 \\
\hline
\end{tabular}

\section{$\mathrm{N}=149$}

The results as shown in table 4.11 indicated that; $42 \%$ of respondents lacked the finances to meet the training cost which was considered very expensive, $34 \%$ stated that there were no training opportunities in the district while $14 \%$ were discovered to have educational level that could not comprehend concepts when delivered in a formal training program. The study also established that some training available targeted only group leader hence leaving out members with business that could benefit more from such training. There was likelihood that non attendance of technical training led to lack of technical knowledge, inadequate managerial skills, lack of planning and lack of market research hence poor uptake of women entrprise funds for business development.

\subsubsection{Marketing plan adopted by micro and small enterprises}

According to Gray (1997), MSEs use the traditional ways of marketing and these no longer give rise to high levels of revenue and product recognition. This factor has also been identified by Burns (1996) in his survey in UK and Nigeria. The survey results showed that $69 \%$ and $70 \%$ of the respondents in the UK and Nigeria respectively agree that poor marketing and sales efforts leads to SMEs failure. This implies that the variable is significantly considered as a major factor influencing business failures in the SMEs sector. Gray (1997), further states that economically, it means that if one fails to market or advertise products then turn over and sales volume will be low and that poor marketing and sales efforts are caused by wrong and untimely advertisements or none at all. Lack of information and market detection are other possible causes as well. Cambridge Small business Research Centre (1992) also identified marketing skills among other factors affecting a firm's growth progression. Furthermore, it appears that when compared to other functions of their business, MSEs owners have a problem with marketing; they appear to give marketing a low priority, often regarding marketing as "something that larger firms do" (Tyebjee, 2003). These observations concurred with the current research findings as shown in figure 4.10 which shows that majority (54\%) of women entrepreneurs in the study area lacked a marketing plan and $46 \%$ had a marketing plan.

Figure 4.9: Response on availability of marketing plan by women enterprise owners in Tharaka South District

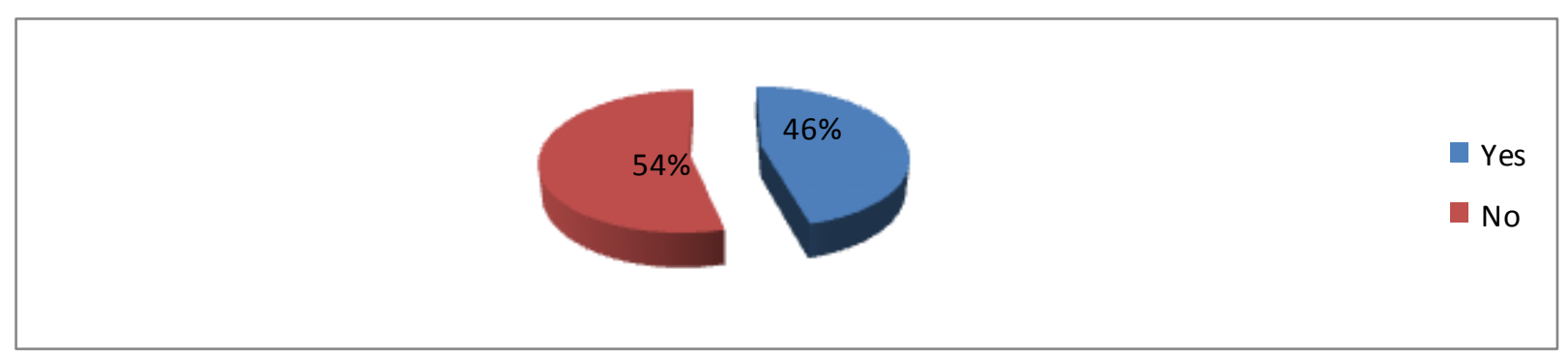

Table 4.12 below illustrates distribution of responses on why some business did not have a marketing plan. Multiple responses were allowed for this questionnaire item and 55\% of women entrepreneurs in Tharaka south district indicated that laws and restrictions on marketing activities barred them from marketing their products and services. Cost involved in marketing was noted by $50 \%$ of respondents, customer perception, security concerns were some of the reasons given against marketing activities hence no plan.

Table 4.11: Response on why some businesses did not have marketing plan

\begin{tabular}{lll}
\hline Reasons & Frequency & Percent \\
\hline Laws and restrictions & 82 & 55 \\
Cost implications & 75 & 50 \\
Local clients perceptions & 28 & 19 \\
Security concerns & 27 & 18 \\
\hline
\end{tabular}




\subsubsection{Products and Services offered by women enterprise owners}

The researcher wanted to know what kind of services and products were being offered by women entrepreneurs in the study area. The results were analyzed and presented as shown in table 4.13. Women entrepreneurs were involved in variety of products and services. These were (33\%) cereals, (30\%) fresh farm produce, milk (19\%), and fuel products such as charcoal, kerosene and firewood at $11 \%$. Other products and services noted were; livestock products (16\%), motor transport (5\%) and shop merchandise being represented by $14 \%$.

Table 4.12: Distribution of responses on products or services offered by women enterprise

\begin{tabular}{|c|c|c|}
\hline \multicolumn{3}{|c|}{ owners } \\
\hline Products/services & Frequency & Percent \\
\hline Cereals & 49 & 33 \\
\hline Fresh farm produce/groceries & 45 & 30 \\
\hline Milk & 28 & 19 \\
\hline Fuel products & 17 & 11 \\
\hline Livestock products & 24 & 16 \\
\hline Motor transport & 8 & 5 \\
\hline Shop merchandise & 21 & 14 \\
\hline
\end{tabular}

\subsubsection{Channels of distribution used by women enterprise owners}

The channels of distribution used by female entrepreneurs in the study area was sought and the findings were presented in table 4.13 indicating that $60 \%$ of entrepreneurs preferred direct sales where they interacted with final consumers of the product or the service offered. The research also established that other types of clients that transacted with the female entrepreneur analyzed were wholesalers at only $6 \%$. This indicates that female entrepreneurs in the study area preferred shorter channels of distribution.

Table 4.13: Response on channels of distribution used by entrepreneurs

\begin{tabular}{lll}
\hline Distribution level & Frequency & Percent \\
\hline Direct to customers & 89 & 60 \\
To retailers & 45 & 30 \\
To wholesalers & 8 & 6 \\
Others & 7 & 4 \\
Total & $\mathbf{1 4 9}$ & $\mathbf{1 0 0}$ \\
\hline
\end{tabular}

\subsubsection{Price determination employed by women enterprise owners}

Price is an element of marketing mix Kuratko, (1998). Andrea (2006) further observed that it was expected that training in marketing in particular would have a direct impact on the performance of the firm in turnover. The following results were found with regard to this variable in Andrea's study: there were significant differences between the declining and improving firms with regard to training in marketing; training in marketing and the strength of the business in marketing skills were positively related; and marketing and turnover growth were also related and this relationship was positive and highly significant. However the researcher sought to know how entrepreneurs were adopting price in their marketing strategy and the findings were as shown in figure 4.10below. 
Figure 4.10: Distribution of responses on bases of price determination of products

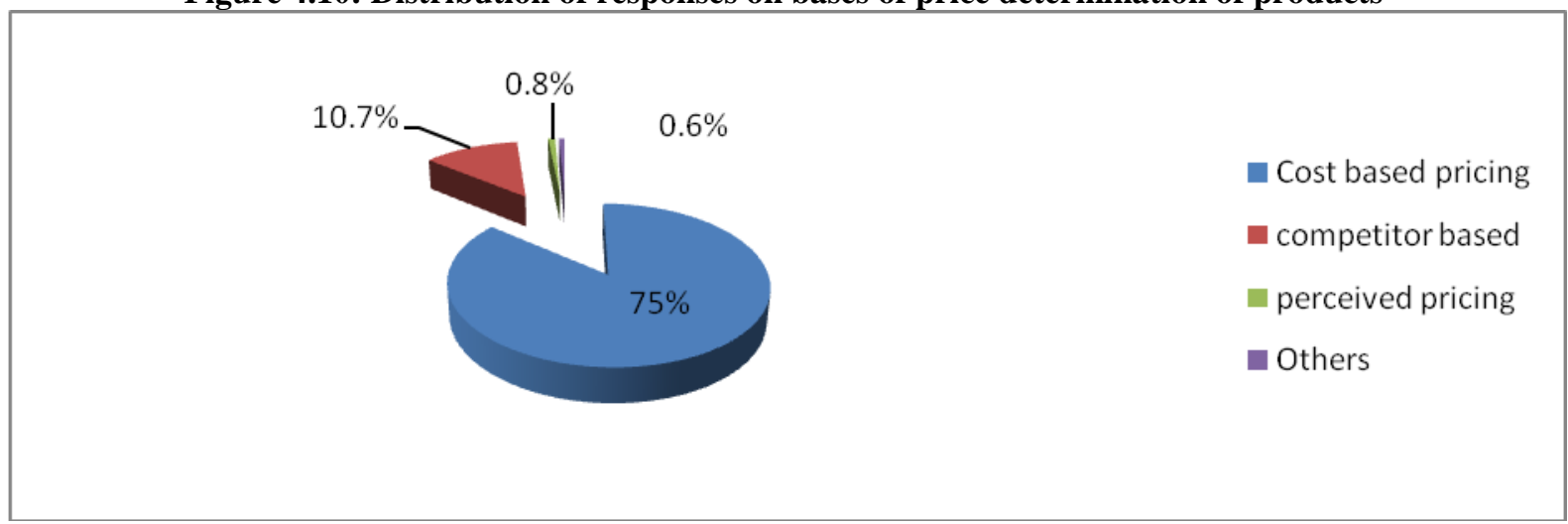

The study established that $75 \%$ of respondents were using cost based pricing strategy, $10.7 \%$ preferred competitor based pricing strategy as they did not want to charge a price which is very different from what their competitor were charging. It should be noted that majority based their prices on cost of producing the service or product.

\subsubsection{Effect of marketing training on performance of enterprise in Tharaka South District}

According to Gray (1997), SMEs use the traditional ways of marketing and these no longer give rise to high levels of revenue and product recognition. This factor has also been identified by Burns (1996), in his survey in UK and Nigeria. The survey results showed that $69 \%$ and $70 \%$ of the respondents in the UK and Nigeria respectively agree that poor marketing and sales efforts influence SMEs failure. This implies that the variable is significantly considered as a major factor influencing business failures in the SMEs sector. Gray (1997), states that economically, it means that failure to market or advertise products then sales turn over and sales volume will be low and that poor marketing and sales efforts are caused by wrong and untimely advertisements or none at all. Lack of information and market detection are other possible causes as well Burns (1996) further states that marketing, which is a common source of economies of scale (EOS), spreading cost of advertising over a greater range of output in media markets, is still low and this impact on their growth of SMEs. Cambridge Small business Research Centre (1992) also identified marketing skills among other factors as affecting a firm's growth progression. This research just like previous research in SMEs performance in relation to marketing activities established that there existed a relationship between the marketing training and performance of enterprise. Table 4.14 indicates that $64 \%$ of respondents agreed that there was indeed a relationship while only $28 \%$ observed that there in no relationship between marketing training and performance of the enterprise.

Figure 4.11: Distribution of response on whether marketing training affected performance of enterprise

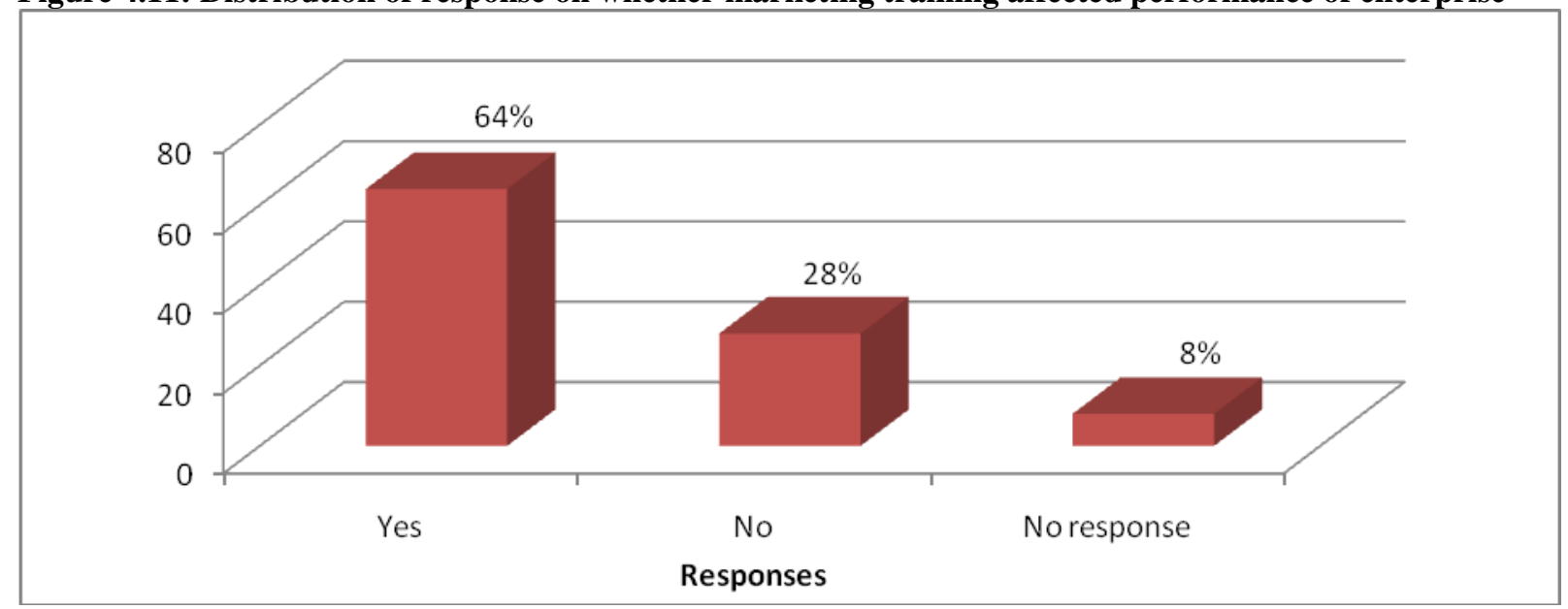

4.10 Correlation Analysis Results on relationship between the independent variables and dependent variables 
The study used the Pearson's product moment method to determine the strength of the relationship. This type of correlation is used when both variables under study are measured at ratio or interval scales and are continuous Mugenda (2003). Table 4.14 details the correlation matrix which indicates that access of women enterprises is positively correlated with all variables under study. Access to funds is correlated with information source at 5 percent significance level (0.316). Social-cultural factors are positively correlated to entrepreneurial skills and access to women fund at 5 percent significance level (0.427) and (0.484) respectively. The table also indicates that there is correlation between entrepreneurial skills and access to women fund at 5 percent significance level of (0.493).

Table 4.14 Correlation matrix of independent variables against growth against the dependent variables

\begin{tabular}{|c|c|c|c|}
\hline Variables & $\begin{array}{l}\text { Information } \\
\text { source }\end{array}$ & Socio-Cultural factors & Entrepreneurial skills \\
\hline Information source & 1 & & \\
\hline Social-cultural factors & .434 & 1 & \\
\hline Entrepreneurial skills & .293 & .427 & 1 \\
\hline $\begin{array}{l}\text { Access to women } \\
\text { enterprise fund }\end{array}$ & .316 & .484 & .493 \\
\hline
\end{tabular}

Correlation is significant at the 0.05 level (2-tailed).

4.11 Multiple regression analysis between dependent variable and independent variables on factors influencing accessibility of women enterprise fund

Table 4.15 shows the summary of the regression analysis that seeks to establish the relationship between access of women fund to information source, socio-cultural factors and entrepreneurial skills. The coefficient of correlation (r), determines the degree (strength) of relationship and its value is between -1 and 1 . A value of 0 implies no relationship, 1 implies a perfect positive relationship, -1 means a negative relationship (Strauss and Corbin,1990). An absolute value of $\mathrm{r}$ between 0.5 and less than 1 implies a strong relationship between the variables. If the value $r$ is greater than 0.3 and less than 0.5 then the relationship is moderate. The relationship is weak if the value of $r$ is less than 0.3 ( Strauss and Corbin, 1990). The regression model below was used to obtain an equation which described the dependent variable in terms of the independent variables.

The regression was calculated using the basic regression model;

According to the regression equation established, it inferred that entrepreneurial skills contributed more to access of women fund followed by socio-cultural skills and to a lesser degree (0.40) information source. At 5\% level of significance and $95 \%$ level of confidence, information source had a 0.031 level of significance; socio cultural factors showed a 0.021 level of significant and entrepreneurial skills showed a 0.01 level of significant; hence the most significant factor was entrepreneurial skills.

Table 4.15: Multiple regression analysis of dependent variable against independent variables on factors on accessibility of women enterprise fund

\begin{tabular}{llll}
\hline \hline Variable & Coefficient & t-Statistic & P Value \\
\hline Constant Term & 0.16 & 2.56 & 0.02 \\
Information source & 0.52 & 2.438 & 0.031 \\
Socio cultural factors & 0.40 & 2.335 & 0.021 \\
Entrepreneurial skills & 0.71 & 2.720 & 0.01 \\
R-squared & 0.6084 & & \\
Adjusted R-squared & 0.56 & & \\
Durbin-Watson value & 2.09 & & \\
\hline \hline
\end{tabular}

Correlation is significant at the 0.05 level (2-tailed).

Hence the resultant regression model is:

Women Fund Access $=\beta_{0}+0.52 \mathrm{IS}+0.4 \mathrm{SC}+0.71 \mathrm{ES}+\mathrm{e}$

The P-value of 0.048 ( Table 4.16) indicates that access of women fund by entrepreneurs in the study is significant at 5 percent level of significance, $\mathrm{P}$ values of less than 0.05 (predetermined significance level) implies that the results are statistically significant Kumar, (2005). The regression had a correlation coefficient $\left(\mathrm{R}^{2}\right)$ of 0.6084 and an adjusted $\mathrm{R}^{2}$ of 0.56 . This means that the source of information, socio-cultural factors and entrepreneurial skills contributed 56 percent of the variations in accessing the women fund.

Table 4.16: Regression analysis summary 


\begin{tabular}{llll}
\hline \hline 0.6084 & 0.5631 & 0.06593 & 0.048 \\
\hline
\end{tabular}

\section{Summary, Conclusions And Recommendations}

\subsection{Summary of Findings}

The research indicated that access to women enterprise fund and studied variables were closely related. In other wards the accessibility of women fund was affected by sources of information, cultural factors and entrepreneurial skills. The research indicated that indeed the accessibility to women fund has contributed positively to the performance of women-owned businesses by offering expansion funds to a larger extend. The research paper analyzed the factor affecting the access to women enterprise fund by women-owned enterprises and came up with a number of findings. These findings may not be exhaustive of the research in this field but give a fairly good picture of how accessibility to women enterprise fund has been affected by sources of information, cultural practices and entrepreneurial skills.

\subsubsection{Information sources and Access to Credit funding by women enterprise fund}

The research question aimed at identifying the effect of information sources on access to women enterprise fund in Tharaka South District. The awareness level of availability of women enterprise fund was found to be very low. The information was obtained from the mainstream media organizations, women group, banks and churches. It was noted that effort to access the funds were not deliberate as very few women entrepreneurs had attempted to apply for the loan from the fund. The institutions approached for women enterprise fund assistance were micro finance institutions, mainstream banks, and women groups and churches in the district.

The study established that majority of women-owned enterprises were not eligible for loans because; they lacked up to date business records, engaged in risky and not viable businesses. The study further established that some women entrepreneurs lacked collateral or guarantors for the loan. More so it was also noted that some women entrepreneur had poor credit history. Women who were eligible and applied for the loan were found out to be successful. However, the uses of loan varied from expanding the business, stating a new business to buying a piece of land and meeting recreational expenses.

\subsubsection{Influence of socio-cultural factors on access to women enterprise fund at Tharaka South District}

Socio-cultural cultural factors were indentified to influence the access of loans to women-owned enterprises. Cultural factors such as religion, education, and women are not being allowed to own anything as men believe that whatever the woman has belongs to the man since he has paid dowry. Most women enterprise owners in the study area belong the Christian religion and specifically to the catholic denomination who have always relied on handouts and hence they do not see the need to look for funds so as to expand their small businesses. The results were analyzed and found to influence loan uptake of female-owned enterprises. The research also discovered that prior negative experience with loan institutions and fear of unknown in business environment impacted on the choice of entrepreneurs to take loans from women enterprise fund in Tharaka South District.

\subsubsection{Effect of entrepreneurial skills on access to women enterprise fund}

The reviewed literature suggested that entrepreneurial skills affected the access and ultimate uptake of business loans in other area. In this study women owned enterprises were analyzed with the main objective of establishing technical training attained related to business operations. The research found out that majority of entrepreneurs had not attended technical training in any of operational areas of their business. Most respondents noted that they lacked finances to meet the cost of available training opportunities while others observed that time, educational level and choice of training participants negatively affected their training aspirations.

The study reviewed literature which indicated that marketing plan is a tool to accelerate growth of the business. This study discovered that majority of businesses did not have a marketing plan. This was attributed to laws and restrictions governing marketing, cost implications and local customer's perception about marketing efforts. The research also identified various products and services offered by women entrepreneurs in Tharaka south district. The products were cereals, groceries, milk, motor transport, and shop merchandise and livestock products. Most businesses were discovered to be using one or two levels of distribution.

Price was mainly determined by cost incurred in producing the service or the product but some traders used competitor based pricing strategy. However, the study also established that marketing training affected the performance of enterprises. The study variables were correlated and were found out that they all affected the 
access of women enterprise fund. Entrepreneurial skills contributed more to accessibility of women enterprise fund followed by effects of socio-cultural factors and to lesser degree information source.

\subsection{Conclusion}

The study was conducted in recognition of importance of women enterprise fund in Kenya's economic development and its potential to improve the livelihoods of many people due to its targeted clientele.

Drawing from the findings of the study, some conclusions can be made. First, the study has confirmed earlier findings that uptake of loan depends on socio-cultural factors, entrepreneurial skills and sources of information in regard to business support services.

Second, the study revealed that entrepreneurial skills contributed more to the accessibility of women enterprise fund followed by socio-cultural factors and to lesser degree information source.

It was also established that as much as entrepreneurs acknowledged the role of marketing training in enhancing business performance, not all businesses had prepared a marketing plan in order to increase performance probably because of lack of support mechanism in regard to cost implication and benefits.

\subsection{Recommendations}

The study recommends a support mechanism to provide adequate information on benefits of women enterprise fund to target recipients. Women owned enterprises should seek relevant information from the right institutions in order to be eligible for the loan. The results indicate most qualified applicants are awarded the loan. Therefore, female-owned SMEs need to do an evaluation based on eligibility criteria to find out if they are qualified for the loans from women enterprise fund so as to benefit from the program. This can be done by a government agency establishment to serve ASAL regions in Kenya with main role of availing information and advising women entrepreneurs about government financial institution.

Having carried out the survey, the researcher notes that there is an information accessibility gap that is unfilled, therefore recommends strategic approaches/considerations for women to acquire relevant and timely information from the right sources. New ways of disseminating information to the target recipient need to be explored because the existing ones have been found to be ineffective. Women business owners in ASAL areas seem not to be using mainstream communication such as radio, television and newspapers since they are not accessible to the women because they do not own the radio or television or they cannot even afford to buy newspapers therefore there is need to establish effective way to communicate such as the use of the churches or training them in their women groups meetings so as to reach the women entrepreneurs in the region.

The women of Tharaka south district should be equipped with entrepreneurial skills; this can be through conducting workshops to teach these women how to start and maintain their businesses in proper state at all times. This will help them to change their attitudes towards business loans and financing institutions and have positive attitude. The researcher therefore recommends entrepreneurial skills equipping programs to ensure that women are educated so that they can be equipped with business operation skills to manage, control and run their businesses properly. The research recommends practical based technical skills equipping workshops for women entrepreneurs in the district. This will address challenges likely to be encountered by more than a third of population with primary school certification as the highest level of education.

The study also recommends the promotion of women enterprise fund in the district to women-owned enterprises in order to realize growth and profitability of SMEs. This will contribute effectively to sustainable development; create wealth for the owner, employment opportunities and poverty alleviation. To realize these, adequate information on loan accessibility and gender stereotype due to cultural practices in ASAL regions should be availed to the women entrepreneurs so as to have a deliberate effort to acquire the loan from women enterprise fund.

\subsection{Areas for further research}

Further research on Micro-credit fund accessibility and the performance of women enterprises in Kenya should be based on aspects such as; The econometric view on micro credit fund and the performance of Women owned businesses in Kenya, other factors that affect the performance of women owned businesses other than micro credit accessibility, interest rates and capacity to pay back and the effect of women microfinance loans on house hold incomes in Kenya should be investigated through further research.

Furthermore, the research only explored the accessibility of women enterprise fund by women enterprise owners in Tharaka South District whose findings might not be similar to other funds provided by another financial institution in a different ASAL area. Other research need to be conducted on different funds or program in other areas so as to compare and corroborate the results of this study.

\section{References}

[1]. Abel, H.W.M and Oketch, H.O. (2009). Women Enterprise Fund: Rapid Assessment Report. Nairobi: Blue Rhino Consult.

[2]. Andrea, O. (2006).Information Technology and Small Businesses: Antecedents and Consequences of Technology Adoption. London: Edward Elgar Publishing. 
[3]. Agarwal, B. (2003). Gender and Land Rights Re-Visited: Exploring New Prospects via the State, Family and Market. Journal of Agrarian Change, Vol.3 (1-2): 184-224

[4]. Alila, P.O., (2002). Women Street Vendors: Nairobi. Institute of Development Studies, University of Nairobi.

[5]. Arinaitwe, J. K. (2006). Factors Constraining the Growth and Survival of Small Scale Businesses. A Developing Countries Analysis. Journal of American Academy of Business, Cambridge, 8(2), 167-178.

[6]. Baran, D. \& Velickait, R. (2008). Building the Theoretical Framework of Entrepreneurship. London: Oxford University Press

[7]. Bari, F., Cheema, A., and Ul-Haque, E. (2005). SME Development in Pakistan: Analysis the constraints to growth .Pakistan Resident Mission .Working Paper No.3.Islamabad.

[8]. Barkham, R., G. Gudgin, M. Hart, and E. Hanvey (1996). The Determinants of Small Firm Growth: An Inter-regional Study in the United Kingdom, 1986-90. London: Jessica Kingsley.

[9]. Barzun, J. \& Graff, H.F. (2004). The Modern Researcher (6 ${ }^{\text {th }}$ Ed). California: Thomson/Wadsworth.

[10]. Bechhofer, F. \& Peterson, L. (2005). Principles of Research Design in the Social Science. New Delhi: Routledge

[11]. Burns, P. And Dewhurst, J. (1996). Small Business and Entrepreneurship, 2nd edition. London: MacMillan.

[12]. Carter, S. and Jones-Evans, D. (Eds.) (2000). Enterprise and Small Business - Principles, Practice and Policy. Harlow: FT Prentice Hall

[13]. Carter, S. \& Shaw, E. (2006).Women’s Business Ownership: Recent Research and Policy Developments. London: Small Business Service.

[14]. Casson,M.(2003). The Entrepreneur: An Economic Theory ( $2^{\text {nd }}$ Ed). Chetenham,U.K: Edward Edgar.

[15]. Cloete, E., Courtney, S., \& Fintz, J. (2002). Small Businesses Acceptance and Adoption of e-commerce in the Western-Cape Province of South Africa. Electronic Journal on Information Systems in Developing Countries, 10(4), 1-13

[16]. Cooper, D.R. \& Schindler, P.S. (2008). Business Research Methods (10 ${ }^{\text {th }}$ Ed). New York: McGraw Hill.

[17]. Cochran, W.G. (2007). Sampling Techniques. New York: John Wily \& Sons.

[18]. Deakins, D. (1999). Entrepreneurship and Small Firm. Second edition. Berkshire: McGraw-Hill.

[19]. Ekumah, E.K. \& Essel,T.T (2001). Gender Access to Credit Under Ghana's Financial Sector Reform: A Case Study of Two Rural banks in the Central Region of Ghana. IFLIP Research Papers No. 01-4.Geneva.ILO.

[20]. Essel, T.T., (1996). The Impact of Rural Banks' Lending operations on Rural Development: ACase Study of Kakun Rural Bank. (An Unpublished M.Phil.Thesis. University of Cape Coast, Cape Coast).

[21]. Gray, K. R., Cooley, W., and Lutabingwa, J. (1997). Small-scale manufacturing in Kenya. Journal of Small Business Management, 1, 66-72.

[22]. Hall, G. (1995). Surviving and Prospering In the Small Firm Sector. London: Routledge.

[23]. Hellen, H. (2002). Micro-Enterprise Development: Nairobi: Food and Research Management.

[24]. Hill, T. (1987). Small Business Production/Operations Management. Nairobi: Macmillan Education Ltd.

[25]. http.www.wef.co.ke/component/content/article 36.

[26]. Joy, J and Mark, D. (2004). Human Resource Development. $3^{\text {rd }}$ Edition. New Delhi: Vinod Vasishta publishers.

[27]. Kenya Institute of Public Policy and Research, (2010). Kenya Economic Report, 2010. Nairobi: KIPPRA.

[28]. Kumah,F.K. \& Agbogah (2000). Has the Finacial Sector Liberalization affected the mode ofSavings Mobilization and of Credit Allocation by Rural Banks in Ghana? Mimeo.ILO/IFLIP

[29]. Kuzilwa,J. (2005). The Role of Credit for Small Business Success: A study of the National Entrepreneurship Fund in Tanzania. The Journal of Entrepreneurship, 14 (2), 131-161

[30]. King, K. and McGrath, S. (2002). Globalization, Enterprise and Knowledge. Manchester: Coleman White Paper Series

[31]. Kothari C.R. (2008). Research Methodology: Methods \& Techniques, (2 ${ }^{\text {nd }}$ Rev. Ed.) New Delhi: New Age International Limited Publishers.

[32]. Kumar, R. (2005). Research Methodology: A Step by Step Guide for Beginners, (2 ${ }^{\text {nd }}$ Ed.). New Delhi: Sage Publication.

[33]. Kuratko, F.D. (1988). Entrepreneurship Education; Emerging Trends and Challenges for the $21^{\text {st }}$ Century. London .Coleman White Paper Series.

[34]. Lois, L. (2004) The Future Of Europe's Rural Peripheries. Oxford: Ashgate Economic Geography Series. Ashgate Publishing, Ltd.

[35]. Macharia,W.L. \& Wanjiru, A. (1998). Formal Credit Financing for Small Scale Enterprises inKenya: A case study of NGOs and Small Scale Women Entrepreneurs in Garment manufacturing Sector of the Textile Industry in Nairobi and Nyeri. Nairobi: Kenyatta University.

[36]. Mutuku, M., (2006). Entrepreneurial Learning among Women Micro-Entrepreneurs in Kenyan Dairy Processing Industry. A paper presented at the $3^{\text {rd }}$ International Entrepreneurship Conference, Nairobi.

[37]. Mody, A. (2001).Infrastructure delivery: Private Initiative and the Public Good. Washington, D.C.The World Bank.

[38]. Mugenda, O.M and Mugenda, A.G. (2003).Research Methods: Quantitative and Qualitative approaches. Nairobi. ACTS Press.

[39]. Mugenda, A.B. (2008).Social Science Research: Theory and Principles.Nairobi.Applied Research and Training Services.

[40]. Nieman, G.H., Hough, J, and Nieuwenhuizen, C. (2003). Entrepreneurship: A South African Perspective. Pretoria: Van Schaik Publishers.

[41]. Olawale, F. and Garwe, D. (2010). Obstacles To the Growth of New SMEs in South Africa: A Principal Component Analysis Approach. Department of Business Management, University of Fort Hare, South Africa. Oxford.

[42]. Otero, M. (1999). Bringing Development Back Into Microfinance. Latin America: ACCION International.

[43]. Peter,B.K. (2001). Impact of Credit on Women-Operated Micro-Enterprises In Uasin Ngishu District,Kenya. Retrieved july 10 ${ }^{\text {th }}$, 2012 from ILO, Geneva, data base:http:/books.google.com.my book/book?

[44]. Republic of Kenya. (1992). Sessional Paper No. 2 of 1992 on Small Enterprise and Jua Kali Development in Kenya. Nairobi. Government printer.

[45]. Republic of Kenya. (1999). Human Population and Housing Census, 1999. Central Bureau of Statistics, Nairobi: Government printer.

[46]. Republic of Kenya. (2005).Sessional Paper No. 2 of 2005 on Development of Micro and Small Enterprises for Wealth Creation for Poverty Reduction. Nairobi: Government printer.

[47]. Republic of Kenya. (2005). Tharaka District Strategic Plan, 2005-2010. Nairobi: National Co-ordination Agency for Population Development.

[48]. Republic of Kenya, (1997). The Eighth National Development Plan 1997-2001. Nairobi: Government Printer.

[49]. Republic of Kenya, (2005). Economic Survey of 2005: Nairobi: Government Printer.

[50]. Republic of Kenya (2007). Kenya Vision 2030: A Globally Competitive and Prosperous Kenya.Nairobi: Government press

[51]. Samiha F. (2002).Globalization and Firm Competitiveness in the Middle East and North Africa Region. Volume 3 of Mediterranean Development Forum Small Business Management, 1, 66-72. 
[52]. Shane, S. (2003). A General Theory Of Entrepreneurship: The Individual Opportunity $\quad$ Nexus.UK: Edward Elgar

[53]. Stevenson, L. \& St-Onge, A. (2005). Support for Growth-Oriented Women Entrepreneurs in Ethiopia, Kenya and Tanzania: An Overview report. Programme on Boosting Employment through Small Enterprise Development Job Creation and Enterprise Department, International labour office, Geneva and private Sector Department, Africa Development Bank, Tunis.

[54]. Sexton, D.L., and Bowman, N. (1985). The entrepreneur: a capable executive and more. Journal of Business Venturing, Vol. 1(1):129-140

[55]. Sun, Xuemin. (2004). The Growth Essence and Ways of the Middle and Small Enterprises. Journal of Zhengzhou University (Philosophy and Social Science Edition), No. 34(4), P. 66-69.

[56]. Timmons, J.A. (1994). New Venture Creation, 4th edition. New York: Irwin.

[57]. Tyebjee, T.T., Bruno, A.V. \& McIntyre, S.H. (2003). 'Growing ventures can anticipate marketing stages', Harvard Business Review, 61(1): 63-66.

[58]. Victor J. (2010) .Small Enterprises to Reap High Returns from ICT Growth. Business Daily. Organization for Economic CoOperation and Development Women Entrepreneurs in SMEs Realizing the Benefits of Globalization and the Knowledge-Based Economy, OECD Publishing

[59]. Wanjohi, A.M. and Mugure, A. (2008). Factors affecting the growth of MSEs in rural areas of Kenya: A case of ICT firms in Kiserian Township, Kajiado District of Kenya. Unpublished Msc Entrepreneurship Research Paper, Nairobi.UON Press.

[60]. Woldie, A., Leighton, P and Adesua, A. (2008).Factors influencing small and medium enterprises: An exploratory study of owner/manager and firm characteristics. London. Banks and Bank Systems. 